\title{
A brief review of cytotoxicity of nanoparticles on mesenchymal stem cells in regenerative medicine
}

This article was published in the following Dove Press journal:

International Journal of Nanomedicine

\author{
Xuan Liu* \\ Ziying Yang* \\ Jiacheng Sun \\ Teng Ma \\ Fei Hua \\ Zhenya Shen \\ Department of Cardiovascular Surgery of \\ the First Affiliated Hospital \& Institute for \\ Cardiovascular Science, Soochow \\ University, Suzhou, People's Republic of \\ China \\ *These authors contributed equally to \\ this work
}

Correspondence: Zhenya Shen; Fei Hua Department of Cardiovascular Surgery, The First Affiliated Hospital of Soochow University, No.899, Pinghai Road, Suzhou 215006, People's Republic of China

Tel +865 I26 778 0I00;

$+8651267781563$

Fax +865 I26 778 0946;

+8651267780946

Email uuzyshen@aliyun.com;

huafeil994@sina.com

\begin{abstract}
Multipotent mesenchymal stem cells have shown great promise for application in regenerative medicine owing to their particular therapeutic effects, such as significant selfrenewability, low immunogenicity, and ability to differentiate into a variety of specialized cells. However, there remain certain complicated and unavoidable problems that limit their further development and application. One of the challenges is to noninvasively monitor the delivery and biodistribution of transplanted stem cells during treatment without relying on behavioral endpoints or tissue histology, and it is important to explore the potential mechanisms to clarify how stem cells work in vivo. To solve these problems, various nanoparticles (NPs) and their corresponding imaging methods have been developed recently and have made great progress. In this review, we mainly discuss NPs used to label stem cells and their toxic effects on the latter, the imaging techniques to detect such NPs, and the current existing challenges in this field.
\end{abstract}

Keywords: mesenchymal stem cells, nanoparticles, toxic effects, imaging methods

\section{Introduction}

Mesenchymal stem cells (MSCs), which are multipotent and can be readily obtained, have shown great promise for treating arthritis, cartilage defects, tissue wounds, stroke, graft versus host disease, myocardial infarction, traumatic brain injury, and even cancer $^{1-3}$ owing to their particular therapeutic effects such as significant self-renewability; low immunogenicity; and ability to differentiate into a variety of specialized cells, control inflammation, and modify the proliferation of, and cytokine production by, immune cells. ${ }^{4}$ Intravenous injection is a common method for transplanting MSCs in both animal models and clinical trials. ${ }^{3,5}$ However, certain barriers significantly limit their long-term efficacy in clinical trials. One of the challenges is to noninvasively monitor the delivery and biodistribution of administered cells during treatment without relying on behavioral endpoints or tissue histology. $3,6,7$

To solve the above problem, reliable and non-invasive tracking of stem cells is urgently needed to understand the long-term fate, migration, and regenerative capability of stem cells, and to evaluate treatment efficacy. ${ }^{8}$ To date, there are three main strategies for cell labeling: direct labeling, indirect labeling, and multimodal labeling. The first strategy is to label stem cells with nanoparticles (NPs), including gold NPs, ${ }^{9}$ iron oxide NPs, ${ }^{10,11}$ organic dyes, and quantum dots (QDs), ${ }^{12,13}$ followed by various imaging techniques, such as photoacoustic imaging, fluorescence imaging, magnetic resonance imaging (MRI), and optical imaging, which are used to detect these materials. For the indirect-labeling method, 
a reporter gene is introduced into cells and then translated into enzymes, receptors, fluorescent or bioluminescent proteins. ${ }^{14-17}$ Among these, green fluorescent protein or luciferase is used frequently for cell labeling so as to provide precise and quantitative information on the fate and distribution of administered stem cells. ${ }^{18,19}$ Multimodal imaging, which combines direct and indirect labeling, can be achieved by using a single label or tracer that is visible using different imaging modalities, or a combination of imaging labels. It is particularly effective in that the strengths of different imaging modalities can be maximized.

At present, various NPs and their corresponding imaging methods have been developed and have shown a promising prospect (Figure 1A-F). In the following review, we will discuss NPs used to label stem cells and their toxic effects on the latter, the imaging techniques to detect such NPs, as well as the currently existing challenges in this field.

\section{NPs and their toxic effects}

Currently, the general definition of NPs are materials with 1-100 nm diameter and surface area $>60 \mathrm{~m}^{2} / \mathrm{cm}^{3}{ }^{20,21}$ Morphology and size are important in determining the physicochemical properties of the NPs, as they not only lead to different rates of cellular uptake, but also interact with biological tissues which cannot be done with other bulk materials. $^{22}$ New synthesis techniques have produced not only spherical NPs, but also NPs of other shapes, such as cubes, ${ }^{23,24}$ prisms, ${ }^{25,26}$ hexagons, ${ }^{24}$ octahedrons, ${ }^{27}$ rods, and tubes. $^{28}$

To date, several engineered NPs, such as QDs, silica NPs, and persistent luminescence NPs, have been developed and employed in medical fields owing to their unique magnetic and/or optical properties as well as their capability to offer real-time methods of tracking intracellular processes at a biomolecular level. $8,29,30$

Besides tracking living transplanted therapeutic stem cells, ${ }^{31}$ synthetic NPs have also being exploited for many other applications, such as manufacturing industrial products, drug and gene delivery, ${ }^{32-34}$ and nanotheranostics. ${ }^{35}$ In particular, some NPs are even used for cancer thermal therapy in clinical trials. ${ }^{36-38}$

Although NPs have afforded significant progress in stem cells tracking and allow sensitive detection and long-term localization under non-invasive conditions in vitro, their toxic side effects on cells still limit their clinical applications. ${ }^{39}$ In general, toxic effects on cells induced by NPs uptake are mainly due to the following reasons. First, most types of NPs are endocytosed by cells and accumulate in cytoplasmic vesicles, particularly lysosomes or late endosomes. ${ }^{40,41}$ However, some NPs may undergo degradation or solubilization due to their sensitivity to the oxidative environment, and thus result in the leaching of free ions or increased abundance of reactive surface groups. ${ }^{39}$ In this case, large amounts of reactive oxygen species will also be generated, which can damage labeled cells when the elevated level of reactive oxygen species persists over prolonged time. ${ }^{42}$ Second, the physical characteristics of NPs can disrupt the cytoskeletal network during NPs internalization into cells. $^{43}$ However, it is the cytoskeleton that plays a major role in the fundamental physiological functions of cells such as shape, motility, division, adhesion, and interaction with the surrounding environment. ${ }^{44}$ When the cytoskeleton changes, its biological function would be affected at the same time, thus resulting in biological toxicity. Third, the internalized NPs can interfere with intracellular signaling pathways such as direct NPsinduced DNA damage, ${ }^{45-47}$ modulation of intracellular signaling cascades, or membrane damage, ${ }^{45}$ and interaction of NPs with cellular transcription/translation machinery. ${ }^{47,48}$ As shown in Figure 2, the disruption of these transduction pathways not only affects the basic physiological functions of cells, but also diminishes their proliferation and differentiation ability. For different NPs which are widely used to label stem cells, their toxic effects are listed in Table 1.

\section{Quantum dots}

QDs are semiconductor nanocrystals with a diameter of approximately $2-10 \mathrm{~nm},{ }^{49}$ possessing excellent optical properties such as narrow, symmetric, and size-tunable emission spectra due to the quantum-confinement effect, ${ }^{50}$ and their adjustable spacing by controlling crystal size. In addition, compared with fluorescent proteins or organic fluorophores, QDs exhibit 10-100 times brighter fluorescence, and 100-1,000 times higher fluorescence stability against photobleaching, which not only enables multicolor fluorescent applications, but also facilitates long-term monitoring of intermolecular and intramolecular interactions in living cells and tissues. Based on these special properties, QDs have been used for bioimaging applications since $1998,{ }^{51,52}$ particularly for labeling different cell lines in in vitro and in vivo studies. ${ }^{53,54}$ 
A
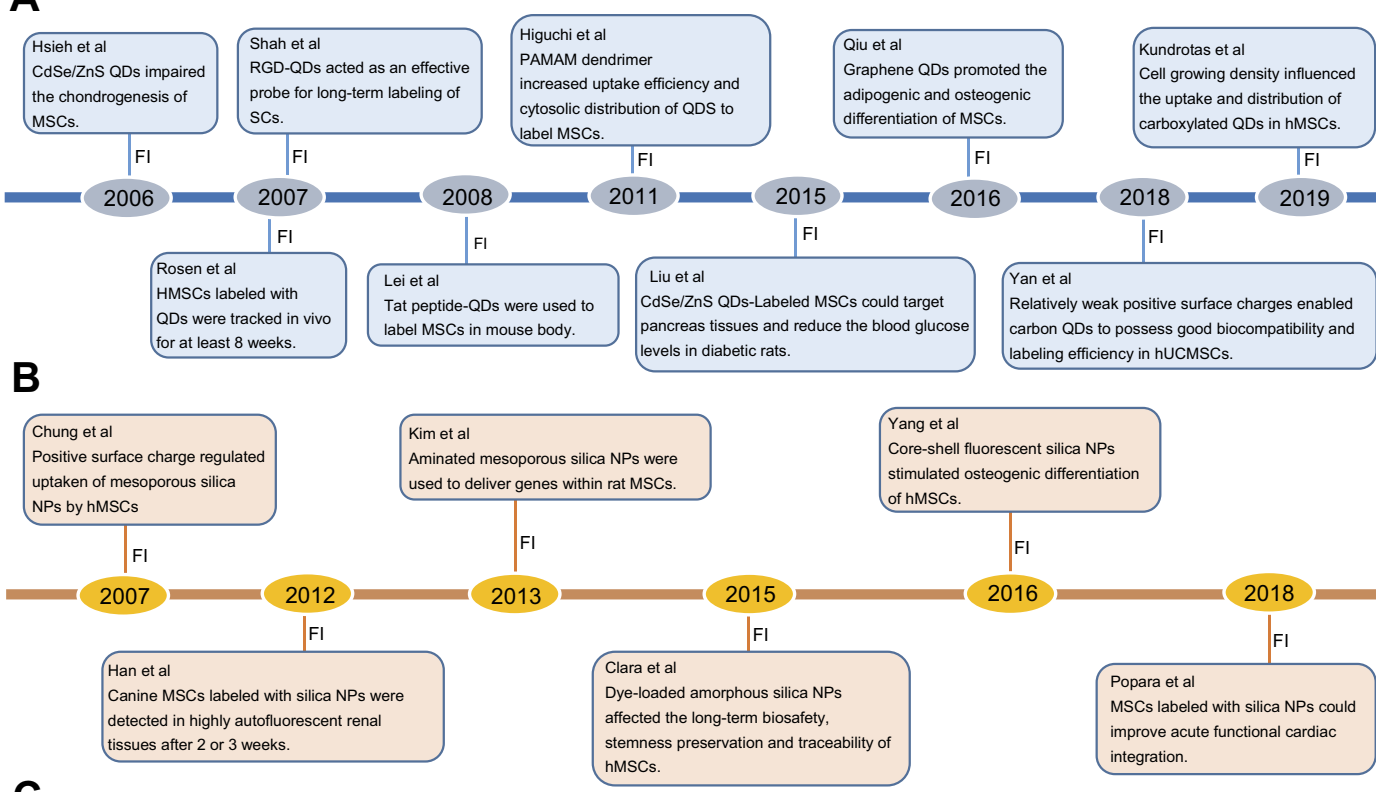

C
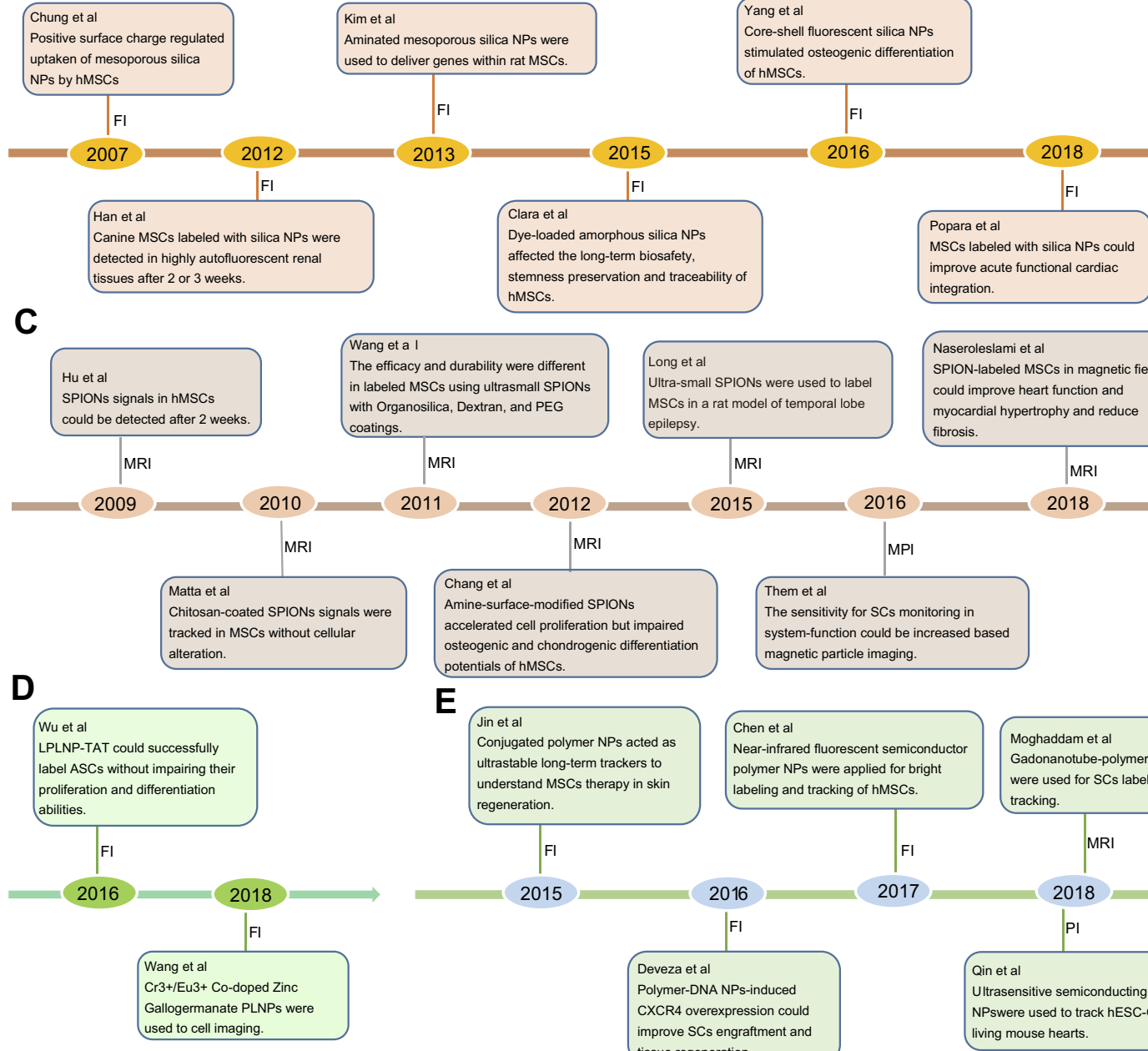

\section{E}

Jinetal

Conjugated polymer NPs acted as ultrastable long-term trackers to understand MSCs therapy in skin regeneration.

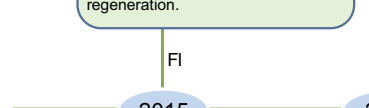

Chen et al

Near-infrared fluorescent semiconductor polymer NPs were applied for bright labeling and tracking of hMSCs.

Naseroleslami et al

SPION-labeled MSCs in magnetic field

could improve heart function and

myocardial hypertrophy and reduce

fibrosis.
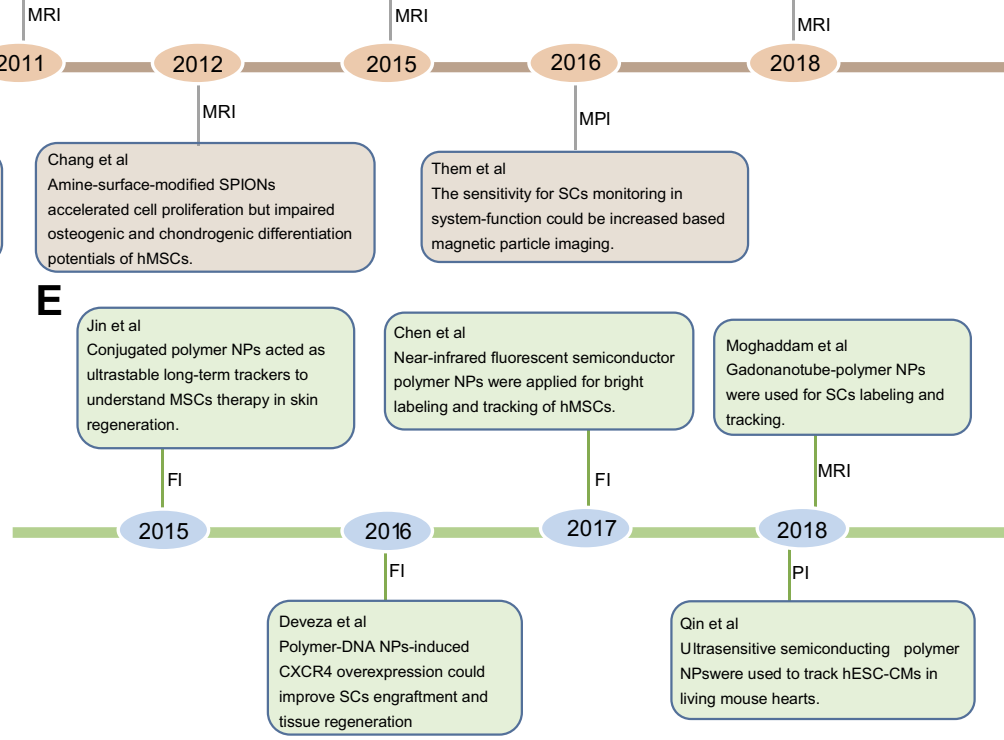

$\mathbf{F}$
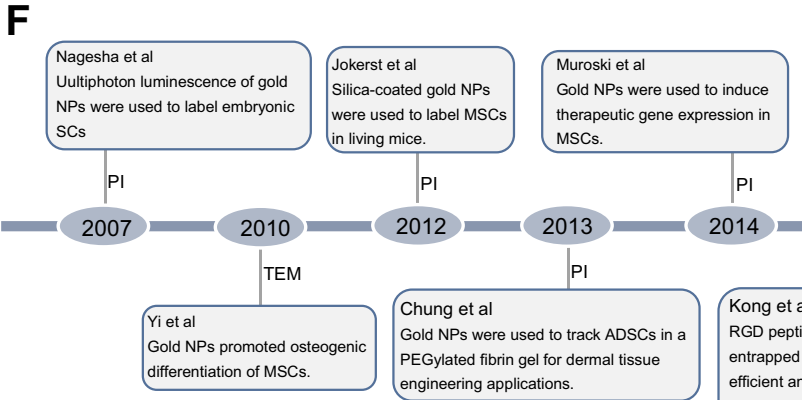

Joydeep et al Shammas et al

Polyethylenimine-coated gold NPs $\quad$ Plasmonic gold NPs were were used to delivery C/EBP beta $\quad$ applied for cellular

gene into hMSCs and founded

enhanced adipogenic differentiation.

tracking and phototherm

cancer cell ablation.

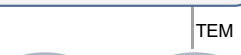

CT

$2015=2016$

2017

PI

Chung et al
Gold NPs were used to track ADSCs in a
PEGylated fibrin gel for dermal tissue
engineering applications.

TEM

Kong et al
RGD peptide-modified dendrimer-
entrapped gold NPs enabled highly
efficient and specific gene delivery
to SCs.

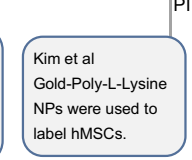

PI P

Gold NPs with tunable RGD density introduced chondrogenic differentiation of hMSCs.

Figure I The timeline of the development of different nanoparticles and the related imaging methods (representative articles). Timeline of (A) QDs, (B) silica NPs, (C) SPIONs, (D) PLNPs, (E) polymer NPs, (F) gold NPs.

Abbreviations: QDs, quantum dots; PAMAM, polyamidoamine; NPs, nanoparticles; SPIONs, superparamagnetic iron oxide nanoparticles; RGD, arginine-glycine-aspartic; LPLNP-TAT, TAT penetrating peptide-bioconjugated long-persistent luminescence nanoparticles; FI, fluorescent imaging; MRI, magnetic resonance imaging; MPI, magnetic particle imaging $\mathrm{PI}$, photoacoustic imaging; TEM, transmission electron microscope; CT, computed tomography. 


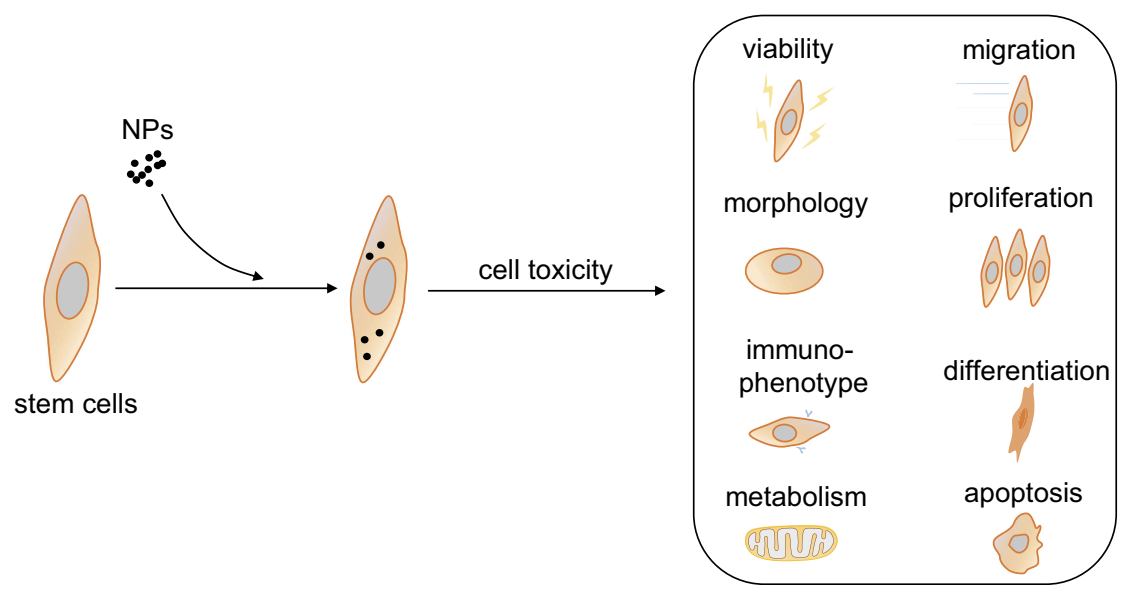

Figure 2 The toxic effects of NPs on cell viability, morphology, immunophenotype, metabolism, migration, proliferation, differentiation, and apoptosis of stem cells. Abbreviation: NPs, nanoparticles.

Two methods are generally considered for labeling stem cells with QDs: the combination of QDs with stem cells surface ${ }^{55}$ and the transduction of QDs into stem cells ${ }^{56,57}$ However, the former would lead to a decrease in the accumulation rate of stem cells in tissues/organs, and separation of QDs from the stem cells surface during in vivo circulation, while the latter results in high cytotoxicity and low transduction efficiency when using physical stimulus methods, such as ultrasonic transduction ${ }^{58}$ and electroporation. ${ }^{59,60}$

In contrast, chemical modification methods, such as cationic liposomes, cell penetrating peptides, and high molecular weight nano-carriers (polymer micelles) were reported as feasible in the labeling of stem cells with QDs. ${ }^{61-63}$ In this regard, Shah and Mao provided a detailed protocol for the labeling of selected integrins on human mesenchymal stem cells (hMSCs) membranes with bioconjugated QDs by optimizing precise concentrations and incubation times. ${ }^{64}$ In addition, stem cells labeled with bioconjugated QDs, whether differentiated or not, could be readily imaged by fluorescence microscopy.

At present, some studies have shown adverse effects while others have shown opposite results. In 2007, Chakraborty et al found no adverse effects on stem cells morphology, viability, proliferation, or differentiation over the duration of their experiments at an optimized labeling efficiency. ${ }^{65}$ In another study, no adverse effects were detected as hMSCs differentiated into osteogenic, chondrogenic, and adipogenic cell lineages, even though hMSCs had been labeled with a concentration of 20-50 nM QDs for at least 22 days, while retaining QDs in their cytoplasm. ${ }^{66}$ In addition, Wang et al labeled MSCs derived from the human amniotic membrane with different doses of QDs and studied their effects over 1-4 days. Their results showed that cells still maintained viability $>80 \%{ }^{67}$

However, others have noticed alterations to stem cells ${ }^{68,69}$ and abnormalities during embryo development when labeled with QDs. ${ }^{70}$ Researchers used QDs to label hMSCs and reported that, even though cellular proliferation and cellcycle distribution were not affected, the chondrogenic and osteogenic differentiation potential of cells was disrupted. ${ }^{68,69}$

Therefore, QDs are not completely toxic, but there is likely to be a confined protocol within which they can be applied without major interference in the processes under study. ${ }^{70}$

\section{Silica NPs}

Silica NPs are nano-scale sized, possessing good stability, biocompatibility and morphological tunability, and have been widely applied in chemical, agricultural, and cosmetic fields. In addition, they are being continuously developed for medical purposes, such as diagnosis, treatment, ${ }^{71-73}$ controlled-release drug delivery, and gene transfection. ${ }^{74,75}$ Silica NPs have been approved as reliable ultrasound contrast agents. ${ }^{76}$ When used as a tracking method, silica NPs are generally labeled with fluorescein. ${ }^{77,78}$ The advantage of this combination is that silicon dioxide not only acts as a matrix to chemically and physically confine the fluorescent dyes, but also protects the dye molecules from external quenchers, thereby increasing their light stability. Furthermore, this combination can also provide a biocompatible and easily functionalized surface. ${ }^{79}$

Among them, exosome-like silica (ELS), which has a unique curvature and cup shape, is more advantageous. This shape provides a double scattering/reflection interface to increase the echo so that it allows lower NPs doses to 
Table I Toxic effects of different nanoparticles used to label stem cells

\begin{tabular}{|c|c|c|c|c|c|c|}
\hline $\begin{array}{l}\text { Stem } \\
\text { cells }\end{array}$ & Species & Nanoparticles & Analysis & Concentration & Main results & $\begin{array}{l}\text { Refer- } \\
\text { ences }\end{array}$ \\
\hline MSC & Human & $\begin{array}{l}\text { Cholera toxin } \\
\text { subunit B QDs }\end{array}$ & $\begin{array}{l}\text { Cell viability, morphology, } \\
\text { proliferation and differentia- } \\
\text { tion capacity }\end{array}$ & $250 \mathrm{pm}-16 \mathrm{nM}$ & No adverse effects & 65 \\
\hline MSC & Human & $\begin{array}{l}\text { RGD-conjugated } \\
\text { QDs }\end{array}$ & $\begin{array}{l}\text { Proliferation and differentia- } \\
\text { tion capacity }\end{array}$ & $20-50 \mathrm{nM}$ & No adverse effects & 66 \\
\hline MSC & Human & CdSe/ZnS QDs & $\begin{array}{l}\text { Cell viability, immunopheno- } \\
\text { typic profiles }\end{array}$ & $0.75-3 \mu g / \mathrm{mL}$ & No adverse effects & 67 \\
\hline MSC & Human & CdSe/ZnS QDs & $\begin{array}{l}\text { Cell viability, proliferation and } \\
\text { differentiation capacity }\end{array}$ & $1.625 \mu \mathrm{g}$ & $\begin{array}{l}\text { Chondrogenic differentiation } \\
\text { impairment }\end{array}$ & 68 \\
\hline MSC & Human & CdSe/ZnS QDs & $\begin{array}{l}\text { Cell viability, proliferation and } \\
\text { differentiation capacity }\end{array}$ & $1.625 \mu \mathrm{g}$ & $\begin{array}{l}\text { osteogenic differentiation } \\
\text { impairment }\end{array}$ & 69 \\
\hline MSC & Rat & CdSe/ZnS QDs & $\begin{array}{l}\text { Cell viability, differentiation } \\
\text { capacity }\end{array}$ & $16 \mu \mathrm{g} / \mathrm{mL}$ & No adverse effects & 185 \\
\hline MSC & Human & Carbon QDs & $\begin{array}{l}\text { Cell viability, differentiation } \\
\text { capacity Single cell sphere } \\
\text { formation capacity }\end{array}$ & $50 \mu \mathrm{g} / \mathrm{mL}$ & No adverse effects & 186 \\
\hline ADSC & Human & Graphene QDs & $\begin{array}{l}\text { Cell viability, metabolic } \\
\text { activity }\end{array}$ & $\begin{array}{l}0.5,1.0, \text { and } \\
2.0 \mathrm{mg} / \mathrm{mL}\end{array}$ & No adverse effects & 187 \\
\hline MSC & Rat & Graphene QDs & $\begin{array}{l}\text { Cell viability, proliferation and } \\
\text { differentiation capacity }\end{array}$ & $50 \mu \mathrm{g} / \mathrm{mL}$ & $\begin{array}{l}\text { Enhanced osteogenic, adipogenic } \\
\text { differentiation }\end{array}$ & 188 \\
\hline MSC & Human & $\begin{array}{l}\text { Mesoporous silica } \\
\text { NPs }\end{array}$ & $\begin{array}{l}\text { Cell adhesion capacity, immu- } \\
\text { nophenotypic profiles }\end{array}$ & $50 \mu \mathrm{g} / \mathrm{mL}$ & $\begin{array}{l}\text { Enhanced adhesion capacity and } \\
\text { Connexin- } 43 \text { expression }\end{array}$ & 73 \\
\hline MSC & Human & $\begin{array}{l}\text { Spherical core- } \\
\text { shell fluorescent } \\
\text { silica NPs }\end{array}$ & $\begin{array}{l}\text { Cell viability, adipogenic dif- } \\
\text { ferentiation capacity }\end{array}$ & $100 \mu \mathrm{g} / \mathrm{mL}$ & $\begin{array}{l}\text { Adipogenic differentiation } \\
\text { impairment }\end{array}$ & 189 \\
\hline MSC & Human & $\begin{array}{l}\text { Core-shell fluor- } \\
\text { escent silica NPs }\end{array}$ & $\begin{array}{l}\text { Cell viability, osteogenic dif- } \\
\text { ferentiation capacity }\end{array}$ & $10 \mu \mathrm{g} / \mathrm{mL}$ & $\begin{array}{l}\text { Osteogenic differentiation } \\
\text { enhancement }\end{array}$ & 190 \\
\hline MSC & Human & $\begin{array}{l}\text { Mesoporous silica } \\
\text { NPs }\end{array}$ & $\begin{array}{l}\text { Cell viability, migration } \\
\text { capacity }\end{array}$ & $\begin{array}{l}100 \text { and } 200 \mu \mathrm{g} / \\
\mathrm{mL}\end{array}$ & No adverse effects & 191 \\
\hline MSC & Human & $\begin{array}{l}\text { Dye-loaded amor- } \\
\text { phous silica NPs }\end{array}$ & $\begin{array}{l}\text { Cell viability, proliferation and } \\
\text { differentiation capacity }\end{array}$ & $50 \mu \mathrm{g} / \mathrm{mL}$ & No adverse effects & 192 \\
\hline MSC & Human & $\begin{array}{l}\text { Mesoporous silica } \\
\text { NPs }\end{array}$ & $\begin{array}{l}\text { Cell viability, proliferation and } \\
\text { differentiation capacity }\end{array}$ & $20 \mu \mathrm{g} / \mathrm{mL}$ & No adverse effects & 86 \\
\hline MSC & Human & $\begin{array}{l}\text { Mesoporous silica } \\
\text { NPs }\end{array}$ & $\begin{array}{l}\text { Cell viability, differentiation } \\
\text { capacity }\end{array}$ & $3-10 \mu \mathrm{g} / \mathrm{mL}$ & No adverse effects & 87 \\
\hline MSC & Human & $\begin{array}{l}\text { Mesoporous silica } \\
\text { NPs }\end{array}$ & $\begin{array}{l}\text { Cell viability, morphology, } \\
\text { immunophenotypic profiles, } \\
\text { proliferation and differentia- } \\
\text { tion capacity }\end{array}$ & $20 \mu \mathrm{g} / \mathrm{mL}$ & No adverse effects & 88 \\
\hline MSC & Human & $\begin{array}{l}\text { Mesoporous silica } \\
\text { NPs }\end{array}$ & $\begin{array}{l}\text { Cell viability, immunophenoty- } \\
\text { pic profiles, proliferation and } \\
\text { differentiation capacity }\end{array}$ & $20 \mu \mathrm{g} / \mathrm{mL}$ & No adverse effects & 89 \\
\hline MSC & Rat & SPIONs & $\begin{array}{l}\text { Cell viability, differentiation } \\
\text { capacity }\end{array}$ & I, $5 \mu \mathrm{g} / \mathrm{mL}$ & $\begin{array}{l}\text { Chondrogenic differentiation } \\
\text { enhancement }\end{array}$ & 193 \\
\hline MSC & Rat & ASP-SPIONs & $\begin{array}{l}\text { Cell viability, apoptosis rate, } \\
\text { intracellular ROS level, mito- } \\
\text { chondrial transmembrane } \\
\text { potential, and differentiation } \\
\text { capacity }\end{array}$ & $30 \mu \mathrm{g} / \mathrm{mL}$ & No adverse effects & 194 \\
\hline
\end{tabular}


Table I (Continued).

\begin{tabular}{|c|c|c|c|c|c|c|}
\hline $\begin{array}{l}\text { Stem } \\
\text { cells }\end{array}$ & Species & Nanoparticles & Analysis & Concentration & Main results & $\begin{array}{l}\text { Refer- } \\
\text { ences }\end{array}$ \\
\hline ADSC & Rat & $\begin{array}{l}\text { PEG/PVP-SPIONs } \\
\text { and PEG/PEI- } \\
\text { SPIONs }\end{array}$ & Cell viability, morphology, & $\begin{array}{l}\mathrm{I} 2,25, \text { and } 50 \\
\mu \mathrm{g} / \mathrm{mL}\end{array}$ & No adverse effects & 195 \\
\hline ADSC & Rat & SPIONs & $\begin{array}{l}\text { Cell viability, morphology, } \\
\text { proliferation capacity }\end{array}$ & $50 \mu \mathrm{g} / \mathrm{mL}$ & No adverse effects & 196 \\
\hline MSC & Human & SPIONs & $\begin{array}{l}\text { Cell viability, differentiation } \\
\text { capacity }\end{array}$ & $25 \mu \mathrm{g} / \mathrm{mL}$ & No adverse effects & 99 \\
\hline MSC & Rat & $\begin{array}{l}\text { HEDP coated } \\
\text { SPIONs }\end{array}$ & $\begin{array}{l}\text { Cell viability, morphology, dif- } \\
\text { ferentiation capacity }\end{array}$ & $25 \mu \mathrm{g} / \mathrm{mL}$ & No adverse effects & 100 \\
\hline MSC & Human & SPIONs & $\begin{array}{l}\text { Cell viability, morphology, dif- } \\
\text { ferentiation capacity }\end{array}$ & $\begin{array}{l}\mathrm{I}, \mathrm{I0} \text {, and } 100 \mu \mathrm{g} \\
\mathrm{Fe} / \mathrm{ml}\end{array}$ & No adverse effects & 101 \\
\hline MSC & Human & SPIONs & $\begin{array}{l}\text { Cell viability, proliferation and } \\
\text { differentiation capacity }\end{array}$ & 13-16 pg Fe/cell & $\begin{array}{l}\text { chondrogenic differentiation } \\
\text { impairment }\end{array}$ & 102 \\
\hline ADSC & Mouse & $\begin{array}{l}\text { Penetrating pep- } \\
\text { tide-bioconjugate- } \\
\text { PLNPs }\end{array}$ & $\begin{array}{l}\text { Cell viability, differentiation } \\
\text { capacity }\end{array}$ & $50 \mu \mathrm{g} / \mathrm{ml}$ & No adverse effects & 109 \\
\hline MSC & Human & $\begin{array}{l}\text { Purified polymer } \\
\text { NPs }\end{array}$ & $\begin{array}{l}\text { Cell viability, proliferation } \\
\text { capacity }\end{array}$ & $\begin{array}{l}0,5,10,20,40 \\
\mu g / \mathrm{mL}\end{array}$ & No adverse effects & 119 \\
\hline MSC & Human & R8-Polymer NPs & $\begin{array}{l}\text { Cell viability, proliferation and } \\
\text { differentiation capacity, } \\
\text { tumorigenicity, immunophe- } \\
\text { notypic profiles }\end{array}$ & $10 \mu \mathrm{g} / \mathrm{mL}$ & No adverse effects & 120 \\
\hline MSC & Porcine & $\begin{array}{l}\text { GNT-Polymer } \\
\text { NPs }\end{array}$ & Cell viability & $\begin{array}{l}10^{14} \mathrm{Gd}^{+} \text {ions/ } \\
\text { cell }\end{array}$ & No adverse effects & 197 \\
\hline $\begin{array}{l}\text { hESC- } \\
\text { CM }\end{array}$ & Human & Polymer NPs & $\begin{array}{l}\text { Cell viability, and immuno- } \\
\text { phenotypic profiles }\end{array}$ & $0,2,4,8 \times 10-9 M$ & No adverse effects & 198 \\
\hline MSC & Human & Gold NPs & $\begin{array}{l}\text { Cell viability, proliferation and } \\
\text { differentiation capacity }\end{array}$ & $10^{12} \mathrm{NPs} / \mathrm{mL}$ & No adverse effects & 135 \\
\hline MSC & Human & $\begin{array}{l}\text { Silica-coated gold } \\
\text { NPs }\end{array}$ & $\begin{array}{l}\text { Cell viability, proliferation and } \\
\text { differentiation capacity }\end{array}$ & $0.0-0.14 \mathrm{nM}$ & No adverse effects & 139 \\
\hline MSC & Rat & $\begin{array}{l}\text { Silica-coated gold } \\
\text { NPs }\end{array}$ & $\begin{array}{l}\text { Cell viability, proliferation } \\
\text { capacity }\end{array}$ & $10^{12} \mathrm{NPs} / \mathrm{mL}$ & No adverse effects & 140 \\
\hline MSC & Mouse & $\begin{array}{l}\text { PEGylated gold } \\
\text { NPs }\end{array}$ & $\begin{array}{l}\text { Cell viability, migration, pro- } \\
\text { liferation, differentiation and } \\
\text { capacity to colonize scaffolds }\end{array}$ & $100 \mu \mathrm{g} / \mathrm{mL}$ & $\begin{array}{l}\text { migration capacity enhancement, } \\
\text { osteoblasts differentiation } \\
\text { enhancement, capacity to colonize } \\
\text { scaffolds enhancement }\end{array}$ & 142 \\
\hline MSC & Human & $\begin{array}{l}\text { TEMPO- } \\
\text { Conjugated gold } \\
\text { NPs }\end{array}$ & $\begin{array}{l}\text { Cell viability, proliferation and } \\
\text { differentiation capacity }\end{array}$ & $0.05-1.00 \mathrm{mM}$ & $\begin{array}{l}\text { Chondrogenic differentiation } \\
\text { enhancement, adipogenic differen- } \\
\text { tiation impairment }\end{array}$ & 145 \\
\hline ADSC & Human & $\begin{array}{l}\text { NAC modified } \\
\text { gold NPs }\end{array}$ & Cell viability, ALP activity & $20 \mu \mathrm{M}$ & cell viability enhancement & 199 \\
\hline
\end{tabular}

produce the same ultrasound contrast, thereby increasing biocompatibility. Meanwhile, compared with most other negatively charged silica NPs due to the presence of hydroxyl groups, ELS NPs are positively charged with amine groups, which greatly increases their affinity for stem cells, thus improving not only the cellular uptake rate but also the ultrasound contrast.
ELS also increases the echogenicity and ultrasound sensitivity of hMSCs. For example, Fang et al injected ELS-labeled hMSCs and Matrigel vectors subcutaneously into nude mouse, PBS and unlabeled cells were also injected as controls, the in vivo ultrasound image results showed a significant increase in echogenicity of transplanted ELS-labeled stem cells compared to controls. ${ }^{80}$ 
It is worth noting that for medical therapy, injected stem cells tend to die because of the harsh environment. ${ }^{81,82}$ To overcome this challenge, growth-promoting survivors could be conjugated with ELS NPs ${ }^{83-85}$ so that the cell viability could be increased. Besides, ELS NPs can be easily chemically modified. In addition to labeling with fluorescein, as described by Fang et al, they can also be coated with helium ions or radionuclides for multimodal imaging. ${ }^{80}$

There are few reports regarding toxic effects on stem cells when labeled with silica NPs, which is of great promise in applications involving regenerative medicine.

In 2008, Huang et al reported that the uptake of mesoporous silica NPs into hMSCs failed to influence their osteogenic differentiation and that silica NPs actin polymerization in MSCs could be enhanced. ${ }^{86}$ Liu et al demonstrated that silica-coated core-shell superparamagnetic iron oxide NPs co-condensed with fluorescein isothiocyanateincorporated mesoporous silica were able to facilitate uptake by hMSCs without affecting their viability and differentiation potential at the same time. ${ }^{87}$ More meaningfully, cyanine dye-doped silica NPs were reported to label hMSCs without affecting viability, proliferation, stemness surface marker expression, and the ability to differentiate into osteocytes. ${ }^{88}$ Also, after the internalization of mesoporous silica NPs conjugated with fluorescein isothiocyanate by hMSCs, Huang et al observed that there were no obvious differences in cell viability, proliferation, and surface markers, compared to unlabeled cells. ${ }^{89}$ In addition, their capability to differentiate into adipocytes, chondrocytes, and osteocytes was also not disrupted.

\section{Superparamagnetic iron oxide nanoparticles (SPIONs)}

SPIONs, a kind of tiny variant of iron fluorophore particles, have been widely used as contrast agents for stem cells tracking markers owing to their biocompatibility, superparamagnetism, nanoscale control, and tailor-made surface coatings. ${ }^{90-93}$ Furthermore, when tracking stem cells, SPIONs can enhance the contrast between different tissues by inducing darker areas (negative contrast). ${ }^{77,94,95}$

However, it should be mentioned that there is still no clear optimal parameter to guide the use of SPIONs in stem cells tracing. One reason is that different doses of SPIONs have been used to label different cell types by containing different types of iron oxide cores and different coatings. Another issue is that they would lose the magnetization vector caused by the applied magnetic field and become highly dispersed when the magnetic field is switched. ${ }^{96}$ Despite this, some researchers have still applied it to stem cells tracking and have obtained satisfactory results, for example, Hua et al used SPIONs to label bone marrow MSCs and successfully tracked the transplanted cells with MRI over different time courses. ${ }^{97}$ Long et al successfully tracked MSCs labeled with ultra-small SPIONs in a rat body. ${ }^{98}$ Naseroleslami et al found SPIONs-labeled MSCs in the presence of magnetic field could markedly improve heart function and myocardial hypertrophy and reduce fibrosis. ${ }^{95}$

There is still controversy concerning the toxicity of SPIONs to labeled cells; some researchers believe that they are toxic, while others believe the opposite. In 2007, Song et al confirmed that internalization of SPIONs (ferumoxides) by hMSCs using lipofectin transfection agents did not affect their cartilage formation, adipogenesis, or osteogenic differentiation. ${ }^{99}$ In 2009, Delcroix et al used SPIONs coated with 1-hydroxyethyl-1, 1-bisphosphonic acid to label rat MSCs. The cells were incubated with NPs for $48 \mathrm{hrs}$, and the authors confirmed that more than $90 \%$ of the cells contained enough iron to allow their detection with no significant alteration to cell viability. In addition, cellular ultrastructure was conserved, and compared to unlabeled rat MSCs, the differential potential for osteogenic and neuronal lineages of rat MSCs did not show significant differences. ${ }^{100}$ In another study, hMSCs were incubated with ferucarbotran for $24 \mathrm{hrs}$ and then labeled with SPIONs. Researchers found that there were no microscopic morphological changes observed up to 12 days after SPION labeling. ${ }^{101}$ However, other researchers holding the opposite view also have their own reasons. Bulte et al reported in 2004 that uptake of SPIONs (ferumoxides) by hMSCs with incubation of the transfection agent polyL-lysine (intracellular iron incorporation of 13-16 pg Fe/cell) would impair their chondrogenic differentiation, and they confirmed that their inhibitory effect is mediated by Fe itself rather than the transfection agents. ${ }^{102}$ Chang et al found that amine-surface-modified SPIONs could accelerate cell proliferation but impair osteogenic and chondrogenic differentiation potentials of hMSCs. ${ }^{103}$

Perhaps, more comprehensive and detailed research is still needed to confirm whether SPIONs have toxic effects on cells and thus arrive at credible results.

\section{Persistent luminescent nanoparticles}

PLNPs are a group of emerging luminescent materials that have been developed and used in biomedical fields over the past decade. PLNPs exhibit unprecedented advantages 
in stem cells tracking due to the following unique features. ${ }^{104}$ The most important is that PLNPs can remain glowing for hours or even days after excitation is stopped, ${ }^{105-107}$ which makes long-term imaging possible without in situ excitation. The other is that PLNPs have excellent signal-to-noise ratios, and can be distinguished from normal tissue autofluorescence. As a consequence, their detectable sensitivity can be greatly improved. For example, Chermont et al pre-charged $\mathrm{Ca}_{0.2} \mathrm{Zn}_{0.9} \mathrm{Mg}_{0.9} \mathrm{Si}_{2}$ $\mathrm{O}_{6}: \mathrm{Eu}^{2+} \mathrm{Dy}^{3+} \mathrm{Mn}^{2+}$ PLNPs with UV light, and then injected them into the mouse. They found that as low as 20 ng PLNPs could generate detectable signals without in situ excitation, and could eliminate autofluorescence from in situ excitation. ${ }^{108}$

To evaluate PLNPs in vivo toxicity, Wu et al employed penetrating peptide-bioconjugated long persistent nanophosphors to track adipose-derived stem cells during wound healing and they confirmed that the labeled adipose-derived stem cells could effectively promote wound healing without the proliferation and differentiation ability impaired. ${ }^{109}$

However, considering the available data, it is not easy to judge the toxic effects of PLNPs on stem cells. Before being applied on a large scale, more stem cells experiments should be conducted to establish more comprehensive and credible conclusions.

\section{Polymer NPs}

Polymer NPs are generally prepared through either dispersion of preformed polymers or polymerization of monomers, ${ }^{110}$ and have been applied for medical purposes widely.

New polymer NPs, such as microgels, dendrimers, and modified polysaccharide NPs, are mostly being used as anticancer drugs, drug and gene delivery carriers, and MRI contrast agents. ${ }^{11-115}$ For stem cells tracking, fluorescent organic dyes are commonly used, not only because they can be physically entrapped in the polymer interior during the preparation of NPs, but also covalently bound to the polymer chain before the preparation of NPs. At present, the most common fluorescent polymer NPs are polystyrene NPs prepared mainly through the emulsion polymerization method.

For example, Jiang et al investigated the uptake of polystyrene NPs by MSCs using confocal fluorescence microscopy and flow cytometry. ${ }^{116}$ In addition to PS, fluorescent polymer NPs can also be prepared with conjugated fluorescent polymers such as poly(arylenediethynlenes), ${ }^{117}$ poly(3,4-ethylenedioxythiophene), poly(thiophene-3-ylacetic acid) and polyacetylene. Polymer NPs prepared by this method can exhibit an amplified fluorescence effect.

Recently, a general strategy has been developed to enhance the photostability of organic fluorophores in biomedical imaging. Using this method, bright and robust fluorescence could be easily observed. ${ }^{118}$

However, despite their wide application, disadvantages such as low incorporation, and inadequate protection of dye molecules leading to consequent leaching, quenching, and photobleaching of the fluorophores, have presented difficult challenges in long-term stem cells tracking.

As for their toxic effects on stem cells, Chen et al found no significant differences between polymer dotlabeled MSCs and unlabeled MSCs in their respective abilities of cell proliferation, differentiation, and phenotypic expression. ${ }^{119}$ Also, the polymer dot-labeled MSCs retained robust self-renewal capacity and multi-lineage differentiation potential. In another study, researchers found that, compared to unlabeled MSCs, cell viability, proliferation and differentiation capacity, tumorigenicity, and immunophenotypic profiles of polymer dot-labeled MSCs also showed no differences. ${ }^{120}$

Furthermore, the existing data still do not fully demonstrate that polymer NPs are safe or have no toxic effects on stem cells. Thus, studies on their toxicity still need to be continued to achieve a more comprehensive understanding.

\section{Gold NPs}

Gold NPs can be designed into different structures and shapes depending on the intended application. ${ }^{121,122}$ These include gold nanospheres, gold nanoshells, and gold nanorods. Moreover, due to the continuous development of gold NPs and the continuous optimization of their properties, more and more gold NPs have been used in the biomedical field, such as gene transfection, ${ }^{123-125}$ drug delivery, ${ }^{126,127}$ antisense gene control, ${ }^{128,129}$ intracellular detection and imaging, ${ }^{130-132}$ and stem cells labeling. ${ }^{133-138}$

Since gold NPs have promising applications in biomedicine, more attention has been paid to the assessment of their risk potential, so as to prolong the life cycle and minimize toxicity in vitro and in vivo. To study the capacity of Silica-Coated Gold Nanorod-labeled murine MSCs, authors conducted MTT cell toxicity assays and the results indicated that Silica-Coated Gold Nanorods with $3 \mathrm{hrs}$ of incubation time lead to no statistically significant change in MSCs metabolic activity compared to unlabeled MSCs. Also, there were no significant 
differences in terms of normal proliferation of the two cell populations. Furthermore, Silica-Coated Gold Nanorod-loaded cells were still easily transformed into osteogenic and adipogenic cell lines, and fivefold greater osteogenic signals could be detected than in control groups, while the adipogenic signal showed nearly the same characteristics. ${ }^{139}$ In another study, it was demonstrated that loading MSCs with gold nanotracers did not alter cell function, and the ability of MSCs to differentiate into adipocytes and osteocytes was maintained. ${ }^{135}$ Later, Ricles et al labeled rat MSCs with Silica-Coated Gold Nanorods and found that compared to control MSCs, the labeled cells were viable for up to 5 days and continued to proliferate, with no significant reduction in cell proliferation. ${ }^{140} \mathrm{Li}$ et al found gold NPs with tunable RGD density could introduce chondrogenic differentiation of hMSCs. ${ }^{141}$ In addition, a study revealed that using pegylated hollow gold NPs to label MSCs caused a clear increase in the cellular migration rate compared to untreated cells. Furthermore, no significant differences were found for the cell-cycle phase percentages for MSCs when treated with pegylated hollow gold NPs compared to control cells. ${ }^{142}$

However, reports on the influence of gold NPs on the differentiation process are scarce, and their mechanism of action is still under debate. Some studies have elucidated that gold NPs could enhance osteogenic differentiation while inhibiting adipogenic differentiation at the same time. ${ }^{143,144}$ For example, in contrast to the suppressive effect of free 2,2,6,6-tetramethylpiperidine-N-oxyl on stem cells differentiation, $\mathrm{Li}$ et al confirmed that TEMPOconjugated gold NPs showed a promoting influence on osteogenic differentiation, with a suppressive influence on adipogenic differentiation of hMSCs. ${ }^{145}$

Based on this, we still cannot conclude whether gold NPs are toxic to stem cells; thus, more studies should be designed and conducted to elucidate their toxic effects on stem cells.

\section{Imaging modalities}

Although stem cells therapy has been applied in many fields, and has achieved some certain efficacy, comprehensive understanding of in vivo behaviors of stem cells is still lacking, which leads to our confusion regarding the contradictory results from current clinical trials. ${ }^{21,23,24}$ Hence, it is of great significance to evaluate the migration, differentiation, and survival of transplanted stem cells, and identify the mechanisms behind these behaviors.
Traditional methods to track the fate of implanted stem cells mainly involve sacrifice of animals or tissue biopsies. However, an invasive and harmful technique is not acceptable for long term and continuous analyses. ${ }^{146,147}$

Recent developments in stem cells therapy require more accurate and noninvasive methods for qualitatively and quantitatively monitoring transplanted cells inside the host, so as to improve the understanding of treatment outcomes and the fate of the stem cells. ${ }^{148}$ To overcome these problems, several tracking modalities, such as fluorescence, magnetic resonance, and photoacoustic imaging combined with engineered NPs possessing unique magnetic and/or optical properties, have been developed and employed in biomedicine to offer real-time imaging of transplanted cells. Although each imaging modality has its own unique advantages, along with intrinsic limitations (as shown in Table 2) which need to be further improved and perfected, their role in the field of regenerative medicine is important and irreplaceable. ${ }^{149}$

\section{Magnetic resonance imaging}

MRI is a basic noninvasive method for human in vivo imaging that uses a powerful magnetic field to detect the nuclear magnetization of hydrogen atoms inside the body, ${ }^{150,151}$ hence, the signal intensity and distribution are closely correlated with water content and the anatomy of the body. ${ }^{152}$ In clinical medicine, MRI is often used to diagnose different diseases and identify cancer metastasis and inflammation sites. ${ }^{153}$

For stem cells tracking, commonly used MRI contrast agents include two major categories based on gadolinium and manganese NPs, such as gadolinium chelating agents ${ }^{154}$ and manganese chloride ${ }^{155}$ and based on iron oxide NPs, such as paramagnetic/superparamagnetic contrast agents. ${ }^{156,157}$ Actually, these agents are ideal in combination with MRI for stem cells tracking because they are able to maintain a strong signal, offer direct and clear cell labeling, and allow non-invasive in vivo scanning.

For example, Blocki et al successfully used MRI to track SPIONs-labeled MSCs, which were encapsulated in collagen-based microcapsules, and then injected intramyocardially. They found that MSCs were progressively released from the microcapsules, and that the signals of labeled MSCs could be monitored for several weeks. ${ }^{158}$ Yao et al also used MRI to monitor SPIONs-labeled endothelial progenitor cells injected into rat myocardium, and detected the signal from iron-positive cells at the injection site 10 days later. ${ }^{159}$ 
Table 2 Evaluation of different imaging modalities

\begin{tabular}{|c|c|c|}
\hline Imaging modality & Advantages & Disadvantages \\
\hline Magnetic resonance imaging & $\begin{array}{l}\text { High spatial resolution }{ }^{31,200} \\
\text { No tissue penetration limit } \\
\text { Allowing quantitative measurements }\end{array}$ & $\begin{array}{l}\text { Relatively low sensitivity }{ }^{31,200} \\
\text { Long imaging time } \\
\text { High cost }\end{array}$ \\
\hline Fluorescence imaging & $\begin{array}{l}\text { High spatial resolution }{ }^{202,203} \\
\text { High sensitivity }^{200}\end{array}$ & $\begin{array}{l}\text { Poor tissue penetration } \\
\text { Interfered by autofluorescence } \\
\text { Low spatial resolution } \\
\text { Lo5 }\end{array}$ \\
\hline Photoacoustic imaging & $\begin{array}{l}\text { Easy expression of functional fluorescent proteins }{ }^{206,207} \\
\text { Multicolor imaging } \\
\text { Activatable }\end{array}$ & $\begin{array}{l}\text { Photobleaching, blinking and cross-linking }{ }^{208,209} \\
\text { Poor tissue penetration } \\
\text { High scattering }\end{array}$ \\
\hline Magnetic particle imaging & $\begin{array}{l}\text { Allowing quantitative and vertical detection } \\
\text { High sensitivity }^{210}\end{array}$ & $\begin{array}{l}\text { Low spatial resolution } \\
\text { Time consuming } \\
\text { Tis,214 }\end{array}$ \\
\hline Multimodality imaging & $\begin{array}{l}\text { Obtain more information }{ }^{176} \\
\text { Strengths of different imaging modalities can be maximized }{ }^{176}\end{array}$ & $\begin{array}{l}\text { Time consuming }{ }^{176} \\
\text { Require precise and thorough planning }{ }^{176}\end{array}$ \\
\hline
\end{tabular}

\section{Fluorescence imaging}

Fluorescent imaging, a tracking method with properties such as low cost, high spatial and temporal sensitivity, and absence of radiation, has been widely used in biomedical applications.

Recently, near-infrared fluorescence (NIRF) molecular imaging, as one kind of fluorescent imaging, has shown great potential. ${ }^{160}$ NIRF is based on a fluorescence optical imaging method that uses excitation light from the nearinfrared spectrum (700-900 nm) to stimulate fluorescent molecules (fluorophores, contrast agents for NIRF) from the ground state (S0) to an excited (S1, S2) state, and when this molecule moves from the excited state to the ground state, it emits detectable fluorescence at longer wavelengths of light.

After reaching the ground state, the fluorescent molecular is available again for new excitation. The advanced properties of near-infrared light, such as low absorption and high scattering characteristics, make deep tissue penetration (to several centimeters) and diffuse expansion possible. In addition, excitation with near-infrared light in the region of $>750 \mathrm{~nm}$ can largely reduce tissue autofluorescence $^{161}$ and thus improve sensitivity. For example, Huang et al injected infrared fluorescent proteinlabeled MSCs into mouse and successfully detected the signal by using NIRF imaging. ${ }^{162}$ In another fluorescent imaging method, Rosen et al demonstrated that single QDs-labeled hMSCs could be easily identified with fluorescent imaging in histologic sections, and were able to signal their location for at least 8 weeks. ${ }^{163}$ Another study investigated the dynamic cell behavior of green fluorescent protein-transduced myoblasts in tibialis anterior muscles of immunocompetent $\mathrm{mdx}$ mouse and immuno-compromised nude mouse over a period of three months using a fluorescent imaging system. ${ }^{164}$

\section{Photoacoustic imaging}

Photoacoustic imaging is currently one of the fastest developing non-invasive hybrid imaging methods. ${ }^{165,166}$ It combines the high temporal and spatial resolution of ultrasound with the excellent contrast and multiplexing capabilities of optical imaging, ${ }^{166}$ so photoacoustic imaging is capable of high spatial resolution mapping in deep tissues $(\approx 6 \mathrm{~cm})$ while maintaining high contrast optical imaging. ${ }^{167,168}$

Contrast agents used in photoacoustic imaging mainly include endogenous agents, small molecule dyes, and NPs. ${ }^{169}$ Among them, gold NPs are used widely and have shown great potential. ${ }^{170,171}$ For example, Jokerst et al used a photoacoustic imaging system to follow MSCs labeled with silica-coated gold nanorods, and successfully obtained a cell detection limit in vivo of 100,000 cells, which was well below the clinically relevant numbers. ${ }^{139}$ Nam et al prepared a PEGylated fibrin gel containing gold NPs-labeled MSCs which were injected into the lateral gastrocnemius of anesthetized Lewis rats, and signals from the labeled MSCs were detected using photoacoustic imaging. ${ }^{172}$ Furthermore, they also performed longitudinal in vivo monitoring of the spatial distribution of labeled MSCs at days 3, 7, and 10 after injection, and successfully obtained signals. 


\section{Magnetic particle imaging (MPI)}

MPI, an imaging modality distinct from MRI, takes advantage of nonlinear SPIONs magnetization behavior, and allows for direct imaging of SPION distribution with positive contrast, as well as high temporal and spatial resolution, ${ }^{173}$ and can longitudinally monitor and quantify MSCs administration in vivo. Compared to existing stem cells tracking techniques, MPI offers near-ideal image contrast, depth penetration, and robustness, these properties make MPI both ultra-sensitive and linearly quantitative.

Importantly, since no biological tissue generates similar superparamagnetic signals that would otherwise interfere, MPI is highly sensitive, with low background noise. ${ }^{173}$ Theoretical prediction by Knopp and Buzug indicates that MPI may be sufficiently sensitive for $1 \mathrm{pg} \mathrm{Fe}$ imaging, which implies a sensitivity able to detect single stem cells.

In 2013, Saritas et al first detected images of labeled stem cells using the MPI system, with a detection limit of approximately $10^{4}$ cells. ${ }^{174}$ Another study performed by Zheng et al in 2015 showed that signals from SPIONlabeled stem cells in rat can also be detected with the MPI system, where a detection limit of approximately 200 cells with $27.03 \pm 0.3 \mathrm{pg}(\mathrm{Fe}) /$ cell was reported. ${ }^{175}$ More importantly, Kolja Them et al used a matching calibration method to detect SPIONs-labeled stem cells, and their results showed that this method can not only reduce artifacts, leading to increased sensitivity, but also can locate and identify a smaller number of labeled stem cells. ${ }^{173}$

\section{Multimodality imaging}

The ideal cell labeling agent in vivo should provide accurate information regarding cell behavior, with high sensitivity and resolution, so that it can be better used in biomedical fields. However, since each method of labeling cells or the method used to detect signals has its own defects, it will still be a challenge to use any single modality to meet the above requirements.

Fortunately, multimodal imaging, which is particularly powerful in comprehensive monitoring of labeled cells, may solve these problems, for it can be performed using a single label or tracer that is visible using different imaging modalities, or a combination of imaging modalities. Thus, the strengths of the different imaging modalities can be maximized. ${ }^{176}$ For example, Rieffel et al have confirmed that the combination of photoacoustic imaging with other modalities can utilize the advantages of both methods in image acquisition and reconstruction. ${ }^{177}$ In addition, Guenoun et al transfected MSCs with a luciferase vector and superparamagnetic iron oxide (SPIO) and found that SPIO signals persisted even after complete loss of fluorescence signals. ${ }^{178}$ In clinical applications, multimodal imaging has been reported to successfully track dendritic cells in melanoma patients by detecting cells labeled with both SPIO and radioactive indium isotopes. ${ }^{179}$

\section{Challenges}

In the field of combining NPs and stem cells applied to regenerative medicine, efficient cell labeling is of great significance for successful imaging. In order to obtain the maximum contrast, it is essential to load a maximal amount of NPs into each cell, because signal intensity is usually proportional to the concentration of the contrast agent. ${ }^{180}$ However, the content of intracellular NPs is also directly proportional to its toxicity.

Although many studies have confirmed that the toxicity of NPs to stem cells is negligible, we still know very little about how abiotic factors might change the time-dependent alteration of NPs properties, and how they would influence its toxicity. ${ }^{181}$ Besides, to assess the potential toxicity of NPs, a better understanding of the relationship between biokinetic parameters and NP properties, such as size, size distribution, charge, shape, agglomeration, and surface characteristics is clearly required. ${ }^{182}$ Further, the influence of biopersistence on the toxicity of NPs and what criteria should be used to assess biopersistence, together with detecting and understanding their kinetics and transformation so as to assess their potential hazards and risks for humans and the environment should also be taken into account. ${ }^{183}$ The next challenge is to perform longitudinal (days or weeks later) cell tracking studies since it was confirmed that the toxicity of NPs is closely related to the extent and mechanism of their uptake, localization and distribution in cells and organs. ${ }^{184}$ We cannot confirm whether NPs being tracked remain inside cells over time, if they have already been secreted from the cells, or taken up by macrophages or other endogenous cells, because previous studies have shown that signal intensity would be decreased with the division and differentiation of stem cells, ${ }^{180}$ also, researchers have detected signals from NPs in macrophages. Besides, challenges also exist in how to select appropriate NPs and the best matched imaging 
modality to generate accurate location information involving the labeled stem cells, so that the obtained images can be accurately analyzed and differentiated from the surrounding tissues.

\section{Conclusions}

Combining NPs with stem cells and applying them to regenerative medicine are major directions for future development. As revealed by extensive research, this application has promising prospects. However, due to the cytotoxic effects of various NPs, systematic and comprehensive in vitro and in vivo studies are urgently needed to assess the toxicological profiles of the chosen NPs and to evaluate their potential influence on selfrenewal and differentiation properties of stem cells before their wider application as contrast agents for stem cells tracking. Specifically, we need to consider the design strategies of NPs, such as size, shape, coating, incubation time and concentration, synthesis method, and the way NPs enter cells, and clarify which kinds of particle properties may cause influences on labeled cells, and by which mechanisms. In addition, while developing new technologies, we should also contemplate whether existing toxicology testing and risk assessment strategies are reliably applicable and sufficiently suited for the variety and complexity of NPs.

With the development of biomedicine, the criteria of low toxicity of NPs and the high accuracy and clarity of imaging modalities to non-invasively detect labeled cells in vitro will be increased as well. Although the combination of hybrid NPs and multimodal imaging has presented some advantages and promising results, developing better biocompatibility and higher-recognition rate NPs combined with high-resolution imaging modalities to track stem cells in vitro will still be extremely important.

\section{Consent for publication}

We confirm the tables in the manuscript are original for this article.

\section{Abbreviation list}

MSCs, mesenchymal stem cells; NPs, nanoparticles; QDs, quantum dots; hMSCs, human mesenchymal stem cells; ELS, exosome-like silica; SPIONs, superparamagnetic iron oxide nanoparticles; PLNPs, persistent luminescent nanoparticles; ASP-SPIONs, SPIONscomplexed amylose nanoparticles cationized with spermine; PEI, poly ethylene imine; PEG, poly ethylene glycol; PVP, poly vinyl pyrrolidone; HEDP, 1-hydroxyethylidene-1.1-bisphosphonic acid; R8, octaarginine; GNT, gadonanotubes; TEMPO, 2,2,6,6-tetramethylpiperidine-N-oxyl; NAC, N-acetyl cysteine; MRI, magnetic resonance imaging; NIRF, nearinfrared fluorescence; MPI, magnetic particle imaging.

\section{Acknowledgments}

This work was supported by National Clinical Key Specialty of Cardiovascular Surgery, Jiangsu Clinical Research Center for Cardiovascular Surgery (BL201451), and National Natural Science Foundation of China (No.21604059 and No.81700361).

\section{Author contributions}

All authors contributed to date analysis, drafting and revising the article, gave final approval of the version to be published, and agree to be accountable for all aspects of the work.

\section{Disclosure}

The authors report no conflicts of interest in this work.

\section{References}

1. Hoogduijn MJ, Roemeling-van Rhijn M, Engela AU, et al. Mesenchymal stem cells induce an inflammatory response after intravenous infusion. Stem Cells Dev. 2013;22(21):2825-2835. doi:10.1089/scd.2013.0193

2. Eggenhofer E, Luk F, Dahlke MH, Hoogduijn MJ. The life and fate of mesenchymal stem cells. Front Immunol. 2014;5:148. doi:10.3389/ fimmu.2014.00148

3. Harting MT, Jimenez F, Xue H, et al. Intravenous mesenchymal stem cell therapy for traumatic brain injury. $J$ Neurosurg. 2009;110 (6):1189-1197. doi:10.3171/2008.9.JNS08158

4. Jiang Y, Jahagirdar BN, Reinhardt RL, et al. Pluripotency of mesenchymal stem cells derived from adult marrow. Nature. 2002;418 (6893):41-49. doi:10.1038/nature00870

5. Wu Y, Zhao RC. The role of chemokines in mesenchymal stem cell homing to myocardium. Stem Cell Rev. 2012;8(1):243-250. doi:10.1007/s12015-011-9293-z

6. Ge J, Guo L, Wang S, et al. The size of mesenchymal stem cells is a significant cause of vascular obstructions and stroke. Stem Cell Rev. 2014;10(2):295-303. doi:10.1007/s12015-013-9492-x

7. Fischer UM, Harting MT, Jimenez F, et al. Pulmonary passage is a major obstacle for intravenous stem cell delivery: the pulmonary first-pass effect. Stem Cells Dev. 2009;18(5):683-692. doi:10.1089/ scd.2008.0253

8. Solanki A, Kim JD, Lee KB. Nanotechnology for regenerative medicine: nanomaterials for stem cell imaging. Nanomedicine. 2008;3 (4):567-578. doi:10.2217/17435889.3.4.567

9. Betzer O, Shwartz A, Motiei M, et al. Nanoparticle-based CT imaging technique for longitudinal and quantitative stem cell tracking within the brain: application in neuropsychiatric disorders. ACS Nano. 2014;8 (9):9274-9285. doi:10.1021/nn503131h 
10. Huang X, Zhang F, Wang Y, et al. Design considerations of iron-based nanoclusters for noninvasive tracking of mesenchymal stem cell homing. ACS Nano. 2014;8(5):4403-4414. doi:10.1021/ nn4062726

11. Mahmoudi M, Hosseinkhani H, Hosseinkhani M, et al. Magnetic resonance imaging tracking of stem cells in vivo using iron oxide nanoparticles as a tool for the advancement of clinical regenerative medicine. Chem Rev. 2011;111(2):253-280. doi:10.1021/ cr1001832

12. Taylor A, Wilson KM, Murray P, Fernig DG, Levy R. Long-term tracking of cells using inorganic nanoparticles as contrast agents: are we there yet? Chem Soc Rev. 2012;41(7):2707-2717. doi:10.1039/c2cs35031a

13. Dupont KM, Sharma K, Stevens HY, Boerckel JD, Garcia AJ, Guldberg RE. Human stem cell delivery for treatment of large segmental bone defects. Proc Natl Acad Sci U S A. 2010;107 (8):3305-3310. doi:10.1073/pnas.0910097107

14. Blasberg RG, Gelovani J. Molecular-genetic imaging: a nuclear medicine-based perspective. Mol Imaging. 2002;1(3):280-300 doi:10.1162/153535002760235472

15. Ponomarev V, Doubrovin M, Serganova I, et al. A novel triple-modality reporter gene for whole-body fluorescent, bioluminescent, and nuclear noninvasive imaging. Eur J Nucl Med Mol Imaging. 2004;31(5):740-751. doi:10.1007/s00259-003-1378-8

16. Tannous BA, Grimm J, Perry KF, Chen JW, Weissleder R, Breakefield XO. Metabolic biotinylation of cell surface receptors for in vivo imaging. Nat Methods. 2006;3(5):391-396. doi: $10.1038 /$ nmeth 875

17. Weissleder R, Moore A, Mahmood U, et al. In vivo magnetic resonance imaging of transgene expression. Nat Med. 2000;6 (3):351-355. doi:10.1038/73219

18. Naumova AV, Modo M, Moore A, Murry CE, Frank JA. Clinical imaging in regenerative medicine. Nat Biotechnol. 2014;32 (8):804-818. doi:10.1038/nbt.2993

19. Wang H, Cao F, De A, et al. Trafficking mesenchymal stem cell engraftment and differentiation in tumor-bearing mice by bioluminescence imaging. Stem Cells. 2009;27(7):1548-1558. doi:10.1002/stem.81

20. Napierska D, Thomassen LC, Lison D, Martens JA, Hoet PH. The nanosilica hazard: another variable entity. Part Fibre Toxicol. 2010;7(1):39. doi:10.1186/1743-8977-7-39

21. Baalousha M, Prasad A, Lead JR. Quantitative measurement of the nanoparticle size and number concentration from liquid suspensions by atomic force microscopy. Environ Sci Process Impacts. 2014;16(6):1338-1347. doi:10.1039/c3em00596h

22. Oberdorster G, Oberdorster E, Oberdorster J. Nanotoxicology: an emerging discipline evolving from studies of ultrafine particles. Environ Health Perspect. 2005;113(7):823-839. doi:10.1289/ ehp.7339

23. Long NV, Chien ND, Hayakawa T, Hirata $H$, Lakshminarayana G, Nogami M. The synthesis and characterization of platinum nanoparticles: a method of controlling the size and morphology. Nanotechnology. 2010;21(3):035605. doi:10.1088/0957-4484/21/3/035605

24. Ahmed J, Sharma S, Ramanujachary KV, Lofland SE, Ganguli AK. Microemulsion-mediated synthesis of cobalt (pure fcc and hexagonal phases) and cobalt-nickel alloy nanoparticles. $J$ Colloid Interface Sci. 2009;336(2):814-819. doi:10.1016/j. jcis.2009.04.062

25. Hu JS, Guo YG, Liang HP, Wan LJ, Jiang L. Three-dimensional self-organization of supramolecular self-assembled porphyrin hollow hexagonal nanoprisms. $J$ Am Chem Soc. 2005;127 (48):17090-17095. doi:10.1021/ja0553912

26. Jitianu M, Goia DV. Zinc oxide colloids with controlled size, shape, and structure. J Colloid Interface Sci. 2007;309(1):78-85. doi:10.1016/j.jcis.2006.12.020
27. Schmidt E, Vargas A, Mallat T, Baiker A. Shape-selective enantioselective hydrogenation on Pt nanoparticles. J Am Chem Soc. 2009;131(34):12358-12367. doi:10.1021/ja9043328

28. Xiao R, Cho SI, Liu R, Lee SB. Controlled electrochemical synthesis of conductive polymer nanotube structures. $\mathrm{J} \mathrm{Am}$ Chem Soc. 2007;129(14):4483-4489. doi:10.1021/ja068924v

29. Deb KD, Griffith M, Muinck ED, Rafat M. Nanotechnology in stem cells research: advances and applications. Front Biosci (Landmark Ed). 2012;17:1747-1760. doi:10.2741/4016

30. Villa C, Erratico S, Razini P, et al. Stem cell tracking by nanotechnologies. Int J Mol Sci. 2010;11(3):1070-1081. doi:10.3390/ijms11031070

31. Gao Y, Cui Y, Chan JK, Xu C. Stem cell tracking with optically active nanoparticles. Am J Nucl Med Mol Imaging. 2013;3 (3):232-246.

32. Lehmann S, Seiffert S, Richtering W. Diffusion of guest molecules within sensitive core-shell microgel carriers. J Colloid Interface Sci. 2014;431:204-208. doi:10.1016/j.jcis.2014.06.014

33. Shcharbin D, Shakhbazau A, Poly BM. amidoamine) dendrimer complexes as a platform for gene delivery. Expert Opin Drug Deliv. 2013;10(12):1687-1698. doi:10.1517/17425247.2013.853661

34. Perez-Herrero E, Fernandez-Medarde A. Advanced targeted therapies in cancer: drug nanocarriers, the future of chemotherapy. Eur J Pharm Biopharm. 2015;93:52-79. doi:10.1016/j.ejpb.2015.03.021

35. Arias JL. Advanced methodologies to formulate nanotheragnostic agents for combined drug delivery and imaging. Expert Opin Drug ～Deliv. 2011;8(12):1589-1608. doi:10.1517/ 17425247.2012.634794

36. Da Rocha EL, Porto LM, Rambo CR. Nanotechnology meets 3D in vitro models: tissue engineered tumors and cancer therapies. Mater Sci Eng C Mater Biol Appl. 2014;34:270-279. doi:10.1016/j.msec.2013.09.033

37. Jung S, Nam J, Hwang S, et al. Theragnostic pH-sensitive gold nanoparticles for the selective surface enhanced Raman scattering and photothermal cancer therapy. Anal Chem. 2013;85 (16):7674-7681. doi:10.1021/ac401390m

38. Shenoi MM, Shah NB, Griffin RJ, Vercellotti GM, Bischof JC. Nanoparticle preconditioning for enhanced thermal therapies in cancer. Nanomedicine. 2011;6(3):545-563. doi:10.2217/ nnm. 10.153

39. Accomasso L, Gallina C, Turinetto V, Giachino C. Stem cell tracking with nanoparticles for regenerative medicine purposes: an overview. Stem Cells Int. 2016;2016:7920358. doi:10.1155/ 2016/1243659

40. Wang T, Bai J, Jiang X, Nienhaus GU. Cellular uptake of nanoparticles by membrane penetration: a study combining confocal microscopy with FTIR spectroelectrochemistry. ACS Nano. 2012;6(2):1251-1259. doi:10.1021/nn203892h

41. Schweiger C, Hartmann R, Zhang F, Parak WJ, Kissel TH, Rivera Gil P. Quantification of the internalization patterns of superparamagnetic iron oxide nanoparticles with opposite charge. J Nanobiotechnol. 2012;10:28. doi:10.1186/1477-3155-10-28

42. Zhu K, Li J, Wang Y, Lai H, Wang C. Nanoparticles-assisted stem cell therapy for ischemic heart disease. Stem Cells Int. 2016;2016:1384658. doi:10.1155/2016/1243659

43. Gupta AK, Gupta M, Yarwood SJ, Curtis AS. Effect of cellular uptake of gelatin nanoparticles on adhesion, morphology and cytoskeleton organisation of human fibroblasts. $J$ Control Release. 2004;95(2):197-207. doi:10.1016/j.jconrel.2003.12.016

44. Yang Y, Bauer C, Strasser G, Wollman R, Julien JP, Fuchs E. Integrators of the cytoskeleton that stabilize microtubules. Cell. 1999;98(2):229-238. doi:10.1016/S0092-8674(00)81017-X

45. Nel A, Xia T, Madler L, Li N. Toxic potential of materials at the nanolevel. Science. 2006;311(5761):622-627. doi:10.1126/ science. 1114397 
46. Gu YJ, Cheng J, Lin CC, Lam YW, Cheng SH, Wong WT. Nuclear penetration of surface functionalized gold nanoparticles. Toxicol Appl Pharmacol. 2009;237(2):196-204. doi:10.1016/j. taap.2009.03.009

47. Singh N, Manshian B, Jenkins GJ, et al. NanoGenotoxicology: the DNA damaging potential of engineered nanomaterials. Biomaterials. 2009;30(23-24):3891-3914. doi:10.1016/j. biomaterials.2009.04.009

48. Pisanic TR 2nd, Blackwell JD, Shubayev VI, Finones RR, Jin S. Nanotoxicity of iron oxide nanoparticle internalization in growing neurons. Biomaterials. 2007;28(16):2572-2581. doi:10.1016/j. biomaterials.2007.01.043

49. Lei Y, Tang H, Yao L, Yu R, Feng M, Zou B. Applications of mesenchymal stem cells labeled with tat peptide conjugated quantum dots to cell tracking in mouse body. Bioconjug Chem. 2008;19(2):421-427. doi:10.1021/bc0700685

50. Norris DJ, Bawendi MG. Measurement and assignment of the size-dependent optical spectrum in CdSe quantum dots. Phys Rev B Condens Matter. 1996;53(24):16338-16346. doi:10.1103/ PhysRevB.53.16338

51. Razgoniaeva N, Rogers S, Moroz P, Cassidy J, Zamkov M. Improving the spectral resolution in fluorescence microscopy through shaped-excitation imaging. Methods Appl Fluoresc. 2018. doi:10.1088/2050-6120/aad81c

52. Chan WC, Nie S. Quantum dot bioconjugates for ultrasensitive nonisotopic detection. Science. 1998;281(5385):2016-2018. doi:10.1126/science.281.5385.2016

53. Higuchi $\mathrm{Y}, \mathrm{Wu} \mathrm{C}$, Chang $\mathrm{KL}$, et al. Polyamidoamine dendrimer-conjugated quantum dots for efficient labeling of primary cultured mesenchymal stem cells. Biomaterials. 2011;32 (28):6676-6682. doi:10.1016/j.biomaterials.2011.05.076

54. Kundrotas G, Karabanovas V, Pleckaitis M, et al. Uptake and distribution of carboxylated quantum dots in human mesenchymal stem cells: cell growing density matters. J Nanobiotechnol. 2019;17(1):39. doi:10.1186/s12951-019-0470-6

55. Chatterjee DK, Fong LS, Zhang Y. Nanoparticles in photodynamic therapy: an emerging paradigm. Adv Drug Deliv Rev. 2008;60(15):1627-1637. doi:10.1016/j.addr.2008.08.003

56. Miyazaki Y, Yukawa H, Nishi H, et al. Adipose tissue-derived stem cell imaging using cadmium-free quantum dots. Cell Med. 2013;6(1-2):91-97. doi:10.3727/215517913X674261

57. Yukawa H, Mizufune S, Mamori C, et al. Quantum dots for labeling adipose tissue-derived stem cells. Cell Transplant. 2009;18(5):591-599.

58. Slotkin JR, Chakrabarti L, Dai HN, et al. In vivo quantum dot labeling of mammalian stem and progenitor cells. Dev Dyn. 2007;236(12):3393-3401. doi:10.1002/dvdy.21235

59. Delehanty JB, Mattoussi H, Medintz IL. Delivering quantum dots into cells: strategies, progress and remaining issues. Anal Bioanal Chem. 2009;393(4):1091-1105. doi:10.1007/s00216-008-2384-2

60. Sun C, Cao Z, Wu M, Lu C. Intracellular tracking of single native molecules with electroporation-delivered quantum dots. Anal Chem. 2014;86(22):11403-11409. doi:10.1021/ac503363m

61. Chang JC, Su HL, Hsu SH. The use of peptide-delivery to protect human adipose-derived adult stem cells from damage caused by the internalization of quantum dots. Biomaterials. 2008;29 (7):925-936. doi:10.1016/j.biomaterials.2007.10.046

62. Toita S, Hasegawa U, Koga H, Sekiya I, Muneta T, Akiyoshi K. Protein-conjugated quantum dots effectively delivered into living cells by a cationic nanogel. J Nanosci Nanotechnol. 2008;8 (5):2279-2285. doi:10.1166/jnn.2008.240

63. Lagerholm BC. Peptide-mediated intracellular delivery of quantum dots. Methods Mol Biol. 2007;374:105-112.

64. Shah BS, Mao JJ. Labeling of mesenchymal stem cells with bioconjugated quantum dots. Methods Mol Biol. 2011;680:61-75.
65. Chakraborty SK, Fitzpatrick JA, Phillippi JA, et al. Cholera toxin B conjugated quantum dots for live cell labeling. Nano Lett. 2007;7(9):2618-2626. doi:10.1021/n10709930

66. Shah BS, Clark PA, Moioli EK, Stroscio MA, Mao JJ. Labeling of mesenchymal stem cells by bioconjugated quantum dots. Nano Lett. 2007;7(10):3071-3079. doi:10.1021/n1071547f

67. Wang G, Zeng G, Wang C, et al. Biocompatibility of quantum dots $(\mathrm{CdSe} / \mathrm{ZnS})$ in human amniotic membrane-derived mesenchymal stem cells in vitro. Biomed Pap Med Fac Univ Palacky Olomouc Czech Repub. 2015;159(2):227-233. doi:10.5507/ bp. 2014.045

68. Hsieh SC, Wang FF, Hung SC, Chen YJ, Wang YJ. The internalized $\mathrm{CdSe} / \mathrm{ZnS}$ quantum dots impair the chondrogenesis of bone marrow mesenchymal stem cells. J Biomed Mater Res B Appl Biomater. 2006;79(1):95-101. doi:10.1002/jbm.b.30517

69. Hsieh SC, Wang FF, Lin CS, Chen YJ, Hung SC, Wang YJ. The inhibition of osteogenesis with human bone marrow mesenchymal stem cells by $\mathrm{CdSe} / \mathrm{ZnS}$ quantum dot labels. Biomaterials. 2006;27(8):1656-1664. doi:10.1016/j.bio materials.2005.09.004

70. Dubertret B, Skourides P, Norris DJ, Noireaux V, Brivanlou AH, Libchaber A. In vivo imaging of quantum dots encapsulated in phospholipid micelles. Science. 2002;298(5599):1759-1762. doi:10.1126/science. 1077194

71. Tang L, Nonporous Silica CJ. Nanoparticles for nanomedicine application. Nano Today. 2013;8(3):290-312. doi:10.1016/j. nantod.2013.04.007

72. Tang F, Li L, Chen D. Mesoporous silica nanoparticles: synthesis, biocompatibility and drug delivery. Adv Mater. 2012;24 (12):1504-1534. doi:10.1002/adma.201104763

73. Popara J, Accomasso L, Vitale E, et al. Silica nanoparticles actively engage with mesenchymal stem cells in improving acute functional cardiac integration. Nanomedicine. 2018;13 (10):1121-1138. doi:10.2217/nnm-2017-0309

74. Slowing II, Vivero-Escoto JL, Wu CW, Lin VS. Mesoporous silica nanoparticles as controlled release drug delivery and gene transfection carriers. Adv Drug Deliv Rev. 2008;60 (11):1278-1288. doi:10.1016/j.addr.2008.03.012

75. Kim TH, Kim M, Eltohamy M, Yun YR, Jang JH, Kim HW. Efficacy of mesoporous silica nanoparticles in delivering BMP-2 plasmid DNA for in vitro osteogenic stimulation of mesenchymal stem cells. J Biomed Mater Res A. 2013;101(6):1651-1660. doi:10.1002/jbm.a.34466

76. Liberman A, Martinez HP, Ta $\mathrm{CN}$, et al. Hollow silica and silica-boron nano/microparticles for contrast-enhanced ultrasound to detect small tumors. Biomaterials. 2012;33(20):5124-5129. doi:10.1016/j.biomaterials.2012.03.066

77. Hu SL, Zhang JQ, $\mathrm{Hu} \mathrm{X}$, et al. In vitro labeling of human umbilical cord mesenchymal stem cells with superparamagnetic iron oxide nanoparticles. J Cell Biochem. 2009;108(2):529-535. doi:10.1002/jcb. 22283

78. Han SM, Lee HW, Bhang DH, Seo KW, Youn HY. Canine mesenchymal stem cells are effectively labeled with silica nanoparticles and unambiguously visualized in highly autofluorescent tissues. BMC Vet Res. 2012;8:145. doi:10.1186/1746-6148-8-145

79. Burns A, Ow H, Wiesner U. Fluorescent core-shell silica nanoparticles: towards "lab on a particle" architectures for nanobiotechnology. Chem Soc Rev. 2006;35(11):1028-1042. doi:10.1039/ B600562B

80. Chen F, Ma M, Wang J, et al. Exosome-like silica nanoparticles: a novel ultrasound contrast agent for stem cell imaging. Nanoscale. 2017;9(1):402-411. doi:10.1039/C6NR08177K

81. Don CW, Murry CE. Improving survival and efficacy of pluripotent stem cell-derived cardiac grafts. J Cell Mol Med. 2013;17 (11):1355-1362. doi:10.1111/jcmm.2013.17.issue-11 
82. Kutschka I, Kofidis T, Chen IY, et al. Adenoviral human BCL-2 transgene expression attenuates early donor cell death after cardiomyoblast transplantation into ischemic rat hearts. Circulation. 2006;114(1 Suppl):I174-80. doi:10.1161/ CIRCULATIONAHA.105.001370

83. Laflamme MA, Chen KY, Naumova AV, et al. Cardiomyocytes derived from human embryonic stem cells in pro-survival factors enhance function of infarcted rat hearts. Nat Biotechnol. 2007;25 (9):1015-1024. doi:10.1038/nbt1276

84. Davis ME, Hsieh PC, Takahashi T, et al. Local myocardial insulin-like growth factor 1 (IGF-1) delivery with biotinylated peptide nanofibers improves cell therapy for myocardial infarction. Proc Natl Acad Sci U S A. 2006;103(21):8155-8160. doi:10.1073/pnas.0602877103

85. Haider H, Jiang S, Idris NM, Ashraf M. IGF-1-overexpressing mesenchymal stem cells accelerate bone marrow stem cell mobilization via paracrine activation of SDF-1alpha/CXCR4 signaling to promote myocardial repair. Circ Res. 2008;103(11):1300-1308. doi:10.1161/CIRCRESAHA.108.186742

86. Huang DM, Chung TH, Hung Y, et al. Internalization of mesoporous silica nanoparticles induces transient but not sufficient osteogenic signals in human mesenchymal stem cells. Toxicol Appl Pharmacol. 2008;231(2):208-215. doi:10.1016/j.taap.2008.04.002

87. Liu HM, Wu SH, Lu CW, et al. Mesoporous silica nanoparticles improve magnetic labeling efficiency in human stem cells. Small. 2008;4(5):619-626. doi:10.1002/smll.200700493

88. Accomasso L, Cibrario Rocchietti E, Raimondo S, et al. Fluorescen silica nanoparticles improve optical imaging of stem cells allowing direct discrimination between live and early-stage apoptotic cells. Small. 2012;8(20):3192-3200. doi:10.1002/smll.201200013

89. Huang DM, Hung Y, Ko BS, et al. Highly efficient cellular labeling of mesoporous nanoparticles in human mesenchymal stem cells: implication for stem cell tracking. FASEB J. 2005;19 (14):2014-2016. doi:10.1096/fj.05-4288fje

90. Santoso MR, Yang PC. Magnetic nanoparticles for targeting and imaging of stem cells in myocardial infarction. Stem Cells Int. 2016;2016:4198790. doi:10.1155/2016/1243659

91. Sharifi S, Behzadi S, Laurent S, Forrest ML, Stroeve P, Mahmoudi M. Toxicity of nanomaterials. Chem Soc Rev. 2012;41(6):2323-2343. doi:10.1039/C1CS15188F

92. Wang YJ, Quercy-Jouvet T, Wang HH, et al. Efficacy and durability in direct labeling of mesenchymal stem cells using ultrasmall superparamagnetic iron oxide nanoparticles with organosilica, dextran, and PEG coatings. Materials (Basel). 2011;4(4):703-715. doi:10.3390/ma4040703

93. Laurent S, Saei AA, Behzadi S, Panahifar A, Mahmoudi M. Superparamagnetic iron oxide nanoparticles for delivery of therapeutic agents: opportunities and challenges. Expert Opin Drug Deliv. 2014;11(9):1449-1470. doi:10.1517/17425247.2014.924501

94. Reddy AM, Kwak BK, Shim HJ, et al. In vivo tracking of mesenchymal stem cells labeled with a novel chitosan-coated superparamagnetic iron oxide nanoparticles using 3.0T MRI. J Korean Med Sci. 2010;25(2):211-219.

95. Naseroleslami M, Aboutaleb N, Parivar K. The effects of superparamagnetic iron oxide nanoparticles-labeled mesenchymal stem cells in the presence of a magnetic field on attenuation of injury after heart failure. Drug Deliv Transl Res. 2018;8(5):1214-1225. doi:10.1007/s13346-018-0490-z

96. Wang LS, Chuang MC, Ho JA. Nanotheranostics-a review of recent publications. Int $J$ Nanomed. 2012;7:4679-4695. doi:10.2147/IJN.S30631

97. Hua P, Wang YY, Liu LB, et al. In vivo magnetic resonance imaging tracking of transplanted superparamagnetic iron oxide-labeled bone marrow mesenchymal stem cells in rats with myocardial infarction. Mol Med Rep. 2015;11(1):113-120. doi:10.3892/mmr.2014.2649
98. Long Q, Li J, Luo Q, et al. MRI tracking of bone marrow mesenchymal stem cells labeled with ultra-small superparamagnetic iron oxide nanoparticles in a rat model of temporal lobe epilepsy. Neurosci Lett. 2015;606:30-35. doi:10.1016/j.neulet.2015.08.040

99. Song YS, Ku JH. Monitoring transplanted human mesenchymal stem cells in rat and rabbit bladders using molecular magnetic resonance imaging. Neurourol Urodyn. 2007;26(4):584-593. doi:10.1002/nau.v26:4

100. Delcroix GJ, Jacquart M, Lemaire L, et al. Mesenchymal and neural stem cells labeled with HEDP-coated SPIO nanoparticles: in vitro characterization and migration potential in rat brain. Brain Res. 2009;1255:18-31. doi:10.1016/j. brainres.2008.12.013

101. Yang CY, Hsiao JK, Tai MF, et al. Direct labeling of hMSC with SPIO: the long-term influence on toxicity, chondrogenic differentiation capacity, and intracellular distribution. Mol Imaging Biol. 2011;13(3):443-451. doi:10.1007/s11307-010-0328-7

102. Bulte JW, Kraitchman DL, Mackay AM, Pittenger MF. Chondrogenic differentiation of mesenchymal stem cells is inhibited after magnetic labeling with ferumoxides. Blood. 2004;104 (10):3410-3412. author reply 2-3.

103. Chang YK, Liu YP, Ho JH, Hsu SC, Lee OK. Amine-surfacemodified superparamagnetic iron oxide nanoparticles interfere with differentiation of human mesenchymal stem cells. J Orthop Res. 2012;30(9):1499-1506. doi:10.1002/jor.21558

104. Maldiney T, Bessiere A, Seguin J, et al. The in vivo activation of persistent nanophosphors for optical imaging of vascularization, tumours and grafted cells. Nat Mater. 2014;13(4):418-426. doi:10.1038/nmat3908

105. Maldiney T, Richard C, Seguin J, Wattier N, Bessodes M, Scherman D. Effect of core diameter, surface coating, and PEG chain length on the biodistribution of persistent luminescence nanoparticles in mice. ACS Nano. 2011;5(2):854-862. doi:10.1021/ nn202666w

106. Li $\mathrm{Z}$, Zhang $\mathrm{Y}, \mathrm{Wu} \mathrm{X}$, et al. In vivo repeatedly charging near-infrared-emitting mesoporous $\mathrm{SiO} 2 / \mathrm{ZnGa} 2 \mathrm{O} 4: \operatorname{cr}(3+)$ persistent luminescence nanocomposites. Adv Sci (Weinh). 2015;2:3. doi:10.1002/advs.201500088

107. Wang Q, Zhang S, Li Z, Zhu Q. Near infrared-emitting $\mathrm{Cr}(3+) / \mathrm{Eu}$ (3+) co-doped zinc gallogermanate persistence luminescent nanoparticles for cell imaging. Nanoscale Res Lett. 2018;13(1):64. doi:10.1186/s11671-018-2477-6

108. le Masne de Chermont Q, Chaneac C, Seguin J, et al. Nanoprobes with near-infrared persistent luminescence for in vivo imaging. Proc Natl Acad Sci U S A. 2007;104(22):9266-9271.

109. Wu SQ, Chi CW, Yang CX, Yan XP. Penetrating peptide-bioconjugated persistent nanophosphors for long-term tracking of adipose-derived stem cells with superior signal-tonoise ratio. Anal Chem. 2016;88(7):4114-4121. doi:10.1021/acs analchem.6b00449

110. Hickey JW, Santos JL, Williford JM, Mao HQ. Control of polymeric nanoparticle size to improve therapeutic delivery. J Control Release. 2015;219:536-547. doi:10.1016/j. jconrel.2015.10.006

111. Abbasi E, Aval SF, Akbarzadeh A, et al. Dendrimers: synthesis, applications, and properties. Nanoscale Res Lett. 2014;9(1):247. doi:10.1186/1556-276X-9-247

112. Kannan RM, Nance E, Kannan S, Tomalia DA. Emerging concepts in dendrimer-based nanomedicine: from design principles to clinical applications. $J$ Intern Med. 2014;276(6):579-617. doi:10.1111/joim.2014.276.issue-6

113. Jedrych M, Borowska K, Galus R, Jodlowska-Jedrych B. The evaluation of the biomedical effectiveness of poly(amido)amine dendrimers generation 4.0 as a drug and as drug carriers: a systematic review and meta-analysis. Int $J$ Pharm. 2014;462 (1-2):38-43. doi:10.1016/j.ijpharm.2013.12.033 
114. Jin G, Mao D, Cai P, et al. Conjugated polymer nanodots as ultrastable long-term trackers to understand mesenchymal stem cell therapy in skin regeneration. Adv Funct Mater. 2015;25 (27):4263-4273. doi:10.1002/adfm.201501081

115. Deveza L, Choi J, Lee J, Huang N, Cooke J, Yang F. Polymer-DNA nanoparticle-induced CXCR4 overexpression improves stem cell engraftment and tissue regeneration in a mouse hindlimb ischemia model. Theranostics. 2016;6(8):1176-1189. doi:10.7150/thno.12866

116. Jiang X, Dausend J, Hafner M, et al. Specific effects of surface amines on polystyrene nanoparticles in their interactions with mesenchymal stem cells. Biomacromolecules. 2010;11 (3):748-753. doi:10.1021/bm901348z

117. Baier MC, Huber J, Mecking S. Fluorescent conjugated polymer nanoparticles by polymerization in miniemulsion. $J$ Am Chem Soc. 2009;131(40):14267-14273. doi:10.1021/ja905077c

118. Huang S, Liu S, Wang K, et al. Highly fluorescent and bioresorbable polymeric nanoparticles with enhanced photostability for cell imaging. Nanoscale. 2015;7(3):889-895. doi:10.1039/C4NR05576D

119. Chen D, Yuan Y, Yu J, Chiu DT, Wu C. Purification of semiconducting polymer dots by size exclusion chromatography prior to cytotoxicity assay and stem cell labeling. Anal Chem. 2018;90 (9):5569-5575. doi:10.1021/acs.analchem.8b03233

120. Chen D, Li Q, Meng Z, et al. Bright polymer dots tracking stem cell engraftment and migration to injured mouse liver. Theranostics. 2017;7(7):1820-1834. doi:10.7150/thno.18614

121. Bastus NG, Comenge J, Puntes V. Kinetically controlled seeded growth synthesis of citrate-stabilized gold nanoparticles of up to $200 \mathrm{~nm}$ : size focusing versus ostwald ripening. Langmuir. 2011;27(17):11098-11105. doi:10.1021/la201938u

122. Grzelczak M, Perez-Juste J, Mulvaney P, Liz-Marzan LM. Shape control in gold nanoparticle synthesis. Chem Soc Rev. 2008;37 (9):1783-1791. doi:10.1039/b711490g

123. Sandhu KK, McIntosh CM, Simard JM, Smith SW, Rotello VM. Gold nanoparticle-mediated transfection of mammalian cells. Bioconjug Chem. 2002;13(1):3-6. doi:10.1021/bc015545c

124. Kong L, Alves CS, Hou W, et al. RGD peptide-modified dendrimer-entrapped gold nanoparticles enable highly efficient and specific gene delivery to stem cells. ACS Appl Mater Interfaces. 2015;7(8):4833-4843. doi:10.1021/am508760w

125. Das J, Choi YJ, Yasuda H, et al. Efficient delivery of C/EBP beta gene into human mesenchymal stem cells via polyethylenimine-coated gold nanoparticles enhances adipogenic differentiation. Sci Rep. 2016;6:33784. doi:10.1038/srep33784

126. Bowman MC, Ballard TE, Ackerson CJ, Feldheim DL, Margolis DM, Melander C. Inhibition of HIV fusion with multivalent gold nanoparticles. $J$ Am Chem Soc. 2008;130 (22):6896-6897. doi:10.1021/ja710321g

127. Han G, You CC, Kim BJ, et al. Light-regulated release of DNA and its delivery to nuclei by means of photolabile gold nanoparticles. Angew Chem Int Ed Engl. 2006;45 (19):3165-3169. doi:10.1002/anie.200600214

128. Rosi NL, Giljohann DA, Thaxton CS, Lytton-Jean AK, Han MS, Mirkin CA. Oligonucleotide-modified gold nanoparticles for intracellular gene regulation. Science. 2006;312 (5776):1027-1030. doi:10.1126/science.1125559

129. Muroski ME, Morgan TJ Jr., Levenson CW, Strouse GF. A gold nanoparticle pentapeptide: gene fusion to induce therapeutic gene expression in mesenchymal stem cells. J Am Chem Soc. 2014;136 (42):14763-14771. doi:10.1021/ja505190q

130. Seferos DS, Giljohann DA, Hill HD, Prigodich AE, Mirkin CA. Nano-flares: probes for transfection and mRNA detection in living cells. J Am Chem Soc. 2007;129(50):15477-15479. doi:10.1021/ ja0776529

131. Prigodich AE, Seferos DS, Massich MD, Giljohann DA, Lane BC, Mirkin CA. Nano-flares for mRNA regulation and detection. ACS Nano. 2009;3(8):2147-2152. doi:10.1021/nn900784f
132. Zheng D, Seferos DS, Giljohann DA, Patel PC, Mirkin CA. Aptamer nano-flares for molecular detection in living cells. Nano Lett. 2009;9(9):3258-3261. doi:10.1021/n1901517b

133. Nagesha D, Laevsky GS, Lampton $P$, et al. In vitro imaging of embryonic stem cells using multiphoton luminescence of gold nanoparticles. Int J Nanomed. 2007;2(4):813-819.

134. Yi C, Liu D, Fong CC, Zhang J, Yang M. Gold nanoparticles promote osteogenic differentiation of mesenchymal stem cells through p38 MAPK pathway. ACS Nano. 2010;4 (11):6439-6448. doi:10.1021/nn101373r

135. Ricles LM, Nam SY, Sokolov K, Emelianov SY, Suggs LJ. Function of mesenchymal stem cells following loading of gold nanotracers. Int J Nanomed. 2011;6:407-416. doi:10.2147/IJN. S25646

136. Chung E, Nam SY, Ricles LM, Emelianov SY, Suggs LJ. Evaluation of gold nanotracers to track adipose-derived stem cells in a PEGylated fibrin gel for dermal tissue engineering applications. Int J Nanomed. 2013;8:325-336. doi:10.2147/IJN. S37465

137. Shammas RL, Fales AM, Crawford BM, et al. Human adipose-derived stem cells labeled with plasmonic gold nanostars for cellular tracking and photothermal cancer cell ablation. Plast Reconstr Surg. 2017;139(4):900e-1000e.

138. Kim T, Lee N, Arifin DR, et al. In vivo micro-CT imaging of human mesenchymal stem cells labeled with gold-poly-L-lysine nanocomplexes. Adv Funct Mater. 2017;27:3.

139. Jokerst JV, Thangaraj M, Kempen PJ, Sinclair R, Gambhir SS. Photoacoustic imaging of mesenchymal stem cells in living mice via silica-coated gold nanorods. ACS Nano. 2012;6 (7):5920-5930. doi:10.1021/nn302042y

140. Ricles LM, Nam SY, Trevino EA, Emelianov SY, Suggs LJ, Dual Gold A. Nanoparticle system for mesenchymal stem cell tracking. $J$ Mater Chem B. 2014;2(46):8220-8230. doi:10.1039/ C4TB00975D

141. Li J, Li X, Zhang J, Kawazoe N, Chen G. Induction of chondrogenic differentiation of human mesenchymal stem cells by biomimetic gold nanoparticles with tunable RGD density. $A d v$ Healthc Mater. 2017;6:14. doi:10.1002/adhm.201700317

142. Mdm E-B, Sancho-Albero M, Crespo A, et al. The effect of PEGylated hollow gold nanoparticles on stem cell migration: potential application in tissue regeneration. Nanoscale. 2017;9 (28):9848-9858. doi:10.1039/C7NR01853C

143. Zhang D, Liu D, Zhang J, Fong C, Yang M. Gold nanoparticles stimulate differentiation and mineralization of primary osteoblasts through the ERK/MAPK signaling pathway. Mater Sci Eng C Mater Biol Appl. 2014;42:70-77. doi:10.1016/j. msec.2014.04.042

144. Li JJ, Kawazoe N, Chen G. Gold nanoparticles with different charge and moiety induce differential cell response on mesenchymal stem cell osteogenesis. Biomaterials. 2015;54:226-236. doi:10.1016/j.biomaterials.2015.03.001

145. Li J, Zhang J, Chen Y, Kawazoe N, Chen G. TEMPO-conjugated gold nanoparticles for reactive oxygen species scavenging and regulation of stem cell differentiation. ACS Appl Mater Interfaces. 2017;9(41):35683-35692. doi:10.1021/acsami.7b12486

146. Lee JK, Jin HK, Endo S, Schuchman EH, Carter JE, Bae JS. Intracerebral transplantation of bone marrow-derived mesenchymal stem cells reduces amyloid-beta deposition and rescues memory deficits in Alzheimer's disease mice by modulation of immune responses. Stem Cells. 2010;28(2):329-343.

147. Pagani FD, DerSimonian H, Zawadzka A, et al. Autologous skeletal myoblasts transplanted to ischemia-damaged myocardium in humans. J Am Coll Cardiol. 2003;41(5):879-888.

148. Peran M, Garcia MA, Lopez-Ruiz E, et al. Functionalized nanostructures with application in regenerative medicine. Int J Mol Sci. 2012;13(3):3847-3886. doi:10.3390/ijms13033847 
149. Willmann JK, van Bruggen N, Dinkelborg LM, Gambhir SS. Molecular imaging in drug development. Nat Rev Drug Discov. 2008;7(7):591-607. doi:10.1038/nrd2290

150. Schroeder T. Imaging stem-cell-driven regeneration in mammals. Nature. 2008;453(7193):345-351. doi:10.1038/nature07043

151. Sinha S, Sinha U. Recent advances in breast MRI and MRS. NMR Biomed. 2009;22(1):3-16. doi:10.1002/nbm.v22:1

152. Logothetis NK. What we can do and what we cannot do with fMRI Nature. 2008;453(7197):869-878. doi:10.1038/nature06976

153. Reimer P, Balzer T. Ferucarbotran (resovist): a new clinically approved RES-specific contrast agent for contrast-enhanced MRI of the liver: properties, clinical development, and applications. Eur Radiol. 2003;13(6):1266-1276.

154. Guenoun J, Koning GA, Doeswijk G, et al. Cationic Gd-DTPA liposomes for highly efficient labeling of mesenchymal stem cells and cell tracking with MRI. Cell Transplant. 2012;21 (1):191-205. doi:10.3727/096368911X593118

155. Sterenczak KA, Meier M, Glage S, et al. Longitudinal MRI contrast enhanced monitoring of early tumour development with manganese chloride $(\mathrm{MnCl} 2)$ and superparamagnetic iron oxide nanoparticles (SPIOs) in a CT1258 based in vivo model of prostate cancer. BMC Cancer. 2012;12:284. doi:10.1186/14712407-12-284

156. Mamani JB, Pavon LF, Miyaki LA, et al. Intracellular labeling and quantification process by magnetic resonance imaging using iron oxide magnetic nanoparticles in rat C6 glioma cell line. Einstein (Sao Paulo). 2012;10(2):216-221. doi:10.1590/S167945082012000200016

157. Vuong QL, Van Doorslaer S, Bridot JL, et al. Paramagnetic nanoparticles as potential MRI contrast agents: characterization, NMR relaxation, simulations and theory. Magma. 2012;25 (6):467-478. doi:10.1007/s10334-012-0326-7

158. Blocki A, Beyer S, Dewavrin JY, et al. Microcapsules engineered to support mesenchymal stem cell (MSC) survival and proliferation enable long-term retention of MSCs in infarcted myocardium. Biomaterials. 2015;53:12-24. doi:10.1016/j. biomaterials.2015.02.075

159. Yao Y, Li Y, Ma G, et al. In vivo magnetic resonance imaging of injected endothelial progenitor cells after myocardial infarction in rats. Mol Imaging Biol. 2011;13(2):303-313. doi:10.1007/s11307010-0328-7

160. Zhu B, Sevick-Muraca EM. A review of performance of near-infrared fluorescence imaging devices used in clinical studies. Br J Radiol. 2015;88(1045):20140547. doi:10.1259/ bjr.20140547

161. Sevick-Muraca EM, Rasmussen JC. Molecular imaging with optics: primer and case for near-infrared fluorescence techniques in personalized medicine. J Biomed Opt. 2008;13(4):041303. doi:10.1117/1.2953185

162. Huang C, Lan W, Wang F, Zhang C, Liu X, Chen Q. AAV-iRFP labelling of human mesenchymal stem cells for near-infrared fluorescence imaging. Biosci Rep. 2017;37:2. doi:10.1042/ BSR20160556

163. Rosen AB, Kelly DJ, Schuldt AJ, et al. Finding fluorescent needles in the cardiac haystack: tracking human mesenchymal stem cells labeled with quantum dots for quantitative in vivo three-dimensional fluorescence analysis. Stem Cells. 2007;25 (8):2128-2138. doi:10.1634/stemcells.2006-0722

164. Yang Z, Wang Y, Li Y, Liu Q, Zeng Q, Xu X. Options for tracking GFP-Labeled transplanted myoblasts using in vivo fluorescence imaging: implications for tracking stem cell fate. $B M C$ Biotechnol. 2014;14:55. doi:10.1186/1472-6750-14-55

165. Wilson K, Homan K, Emelianov S. Biomedical photoacoustics beyond thermal expansion using triggered nanodroplet vaporization for contrast-enhanced imaging. Nat Commun. 2012;3:618. doi: $10.1038 /$ ncomms 1627
166. Wang LV, Hu S. Photoacoustic tomography: in vivo imaging from organelles to organs. Science. 2012;335(6075):1458-1462. doi: $10.1126 /$ science. 1216210

167. Yao J, Wang LV. Photoacoustic tomography: fundamentals, advances and prospects. Contrast Media Mol Imaging. 2011;6 (5):332-345. doi:10.1002/cmmi.443

168. Weber J, Beard PC, Bohndiek SE. Contrast agents for molecular photoacoustic imaging. Nat Methods. 2016;13(8):639-650. doi:10.1038/nmeth.3929

169. Lemaster JE, Jokerst JV. What is new in nanoparticle-based photoacoustic imaging? Wiley Interdiscip Rev Nanomed Nanobiotechnol. 2017;9:1. doi:10.1002/wnan.1404

170. De la Zerda A, Zavaleta C, Keren S, et al. Carbon nanotubes as photoacoustic molecular imaging agents in living mice. Nat Nanotechnol. 2008;3(9):557-562. doi:10.1038/nnano.2008.231

171. de la Zerda A, Liu Z, Bodapati S, et al. Ultrahigh sensitivity carbon nanotube agents for photoacoustic molecular imaging in living mice. Nano Lett. 2010;10(6):2168-2172. doi:10.1021/ nl1017157

172. Nam SY, Ricles LM, Suggs LJ, Emelianov SY. In vivo ultrasound and photoacoustic monitoring of mesenchymal stem cells labeled with gold nanotracers. PLoS One. 2012;7(5):e37267. doi:10.1371/ journal.pone.0037267

173. Them K, Salamon J, Szwargulski P, et al. Increasing the sensitivity for stem cell monitoring in system-function based magnetic particle imaging. Phys Med Biol. 2016;61(9):3279-3290. doi:10.1088/0031-9155/61/9/3279

174. Saritas EU, Goodwill PW, Croft LR, et al. Magnetic particle imaging (MPI) for NMR and MRI researchers. J Magn Reson. 2013;229:116-126. doi:10.1016/j.jmr.2012.11.029

175. Zheng B, Vazin T, Goodwill PW, et al. Magnetic particle imaging tracks the long-term fate of in vivo neural cell implants with high image contrast. Sci Rep. 2015;5:14055. doi:10.1038/srep 14055

176. Srinivas M, Melero I, Kaempgen E, Figdor CG, de Vries IJ. Cell tracking using multimodal imaging. Contrast Media Mol Imaging. 2013;8(6):432-438. doi:10.1002/cmmi.1561

177. Rieffel J, Chitgupi U, Lovell JF. Recent advances in higher-order, multimodal, biomedical imaging agents. Small. 2015;11 (35):4445-4461. doi:10.1002/smll.201500735

178. Guenoun J, Ruggiero A, Doeswijk G, et al. In vivo quantitative assessment of cell viability of gadolinium or iron-labeled cells using MRI and bioluminescence imaging. Contrast Media Mol Imaging. 2013;8(2):165-174. doi:10.1002/cmmi.1513

179. de Vries IJ, Lesterhuis WJ, Barentsz JO, et al. Magnetic resonance tracking of dendritic cells in melanoma patients for monitoring of cellular therapy. Nat Biotechnol. 2005;23 (11):1407-1413. doi:10.1038/nbt1154

180. Meir R, Popovtzer R. Cell tracking using gold nanoparticles and computed tomography imaging. Wiley Interdiscip Rev Nanomed Nanobiotechnol. 2018;10:2. doi:10.1002/wnan.1480

181. Haase A, Tentschert J, Luch A. Nanomaterials: a challenge for toxicological risk assessment? EXS. 2012;101:219-250. doi:10.1007/978-3-7643-8340-4 8

182. Carlander U, Moto TP, Desalegn AA, Yokel RA, Johanson G. Physiologically based pharmacokinetic modeling of nanoceria systemic distribution in rats suggests dose- and route-dependent biokinetics. Int J Nanomed. 2018;13:2631-2646. doi:10.2147/ IJN.S177627

183. Carlander U, Li D, Jolliet O, Emond C, Johanson G. Toward a general physiologically-based pharmacokinetic model for intravenously injected nanoparticles. Int $J$ Nanomed. 2016;11:625-640. doi:10.2147/IJN.S94370

184. Laux P, Riebeling C, Booth AM, et al. Biokinetics of nanomaterials: the role of biopersistence. NanoImpact. 2017;6:69-80. doi:10.1016/j.impact.2017.03.003 
185. Liu H, Tang W, Li C, et al. CdSe/ZnS quantum dots-labeled mesenchymal stem cells for targeted fluorescence imaging of pancreas tissues and therapy of type 1 diabetic rats. Nanoscale Res Lett. 2015;10(1):959. doi:10.1186/s11671-015-0959-3

186. Yan J, Hou S, Yu Y, et al. The effect of surface charge on the cytotoxicity and uptake of carbon quantum dots in human umbilical cord derived mesenchymal stem cells. Colloids Surf B Biointerfaces. 2018;171:241-249. doi:10.1016/j.colsurfb.2018.07.036

187. Kim J, Song SH, Jin Y, et al. Multiphoton luminescent graphene quantum dots for in vivo tracking of human adipose-derived stem cells. Nanoscale. 2016;8(16):8512-8519. doi:10.1039/C6NR02143C

188. Qiu J, Li D, Mou X, et al. Effects of graphene quantum dots on the self-renewal and differentiation of mesenchymal stem cells. Adv Healthc Mater. 2016;5(6):702-710. doi:10.1002/adhm.201500770

189. Yang X, Liu X, Li Y, et al. The negative effect of silica nanoparticles on adipogenic differentiation of human mesenchymal stem cells. Mater Sci Eng C Mater Biol Appl. 2017;81:341-348. doi:10.1016/j.msec.2017.07.042

190. Yang X, Li Y, Liu X, et al. The stimulatory effect of silica nanoparticles on osteogenic differentiation of human mesenchymal stem cells. Biomed Mater. 2016;12(1):015001. doi:10.1088/ 1748-605X/12/1/015001

191. Paris JL, de la Torre P, Manzano M, Cabanas MV, Flores AI, ValletRegi M. Decidua-derived mesenchymal stem cells as carriers of mesoporous silica nanoparticles. Acta Biomater. 2016;33:275-282.

192. Gallina C, Capeloa T, Saviozzi S, et al. Human mesenchymal stem cells labelled with dye-loaded amorphous silica nanoparticles: long-term biosafety, stemness preservation and traceability in the beating heart. J Nanobiotechnol. 2015;13:77. doi:10.1186/ s12951-015-0141-1

193. Jiang F, Xiao JJ, Lu YT, et al. [Effect of superparamagnetic iron oxide on differentiation of rat bone marrow stem cells into chondrocytes in vitro]. Nan Fang Yi Ke Da Xue Xue Bao. 2017;37(5):652-658.

194. Lin BL, Zhang JZ, Lu LJ, et al. Superparamagnetic iron oxide nanoparticles-complexed cationic amylose for in vivo magnetic resonance imaging tracking of transplanted stem cells in stroke. Nanomaterials (Basel). 2017;7:5. doi:10.3390/nano7120458

195. Yang G, Ma W, Zhang B, Xie Q. The labeling of stem cells by superparamagnetic iron oxide nanoparticles modified with PEG/ PVP or PEG/PEI. Mater Sci Eng C Mater Biol Appl. 2016;62:384-390. doi:10.1016/j.msec.2016.01.090

196. Zhu LL, Zhang Z, Jiang HS, Chen H, Chen Y, Dai YT. Superparamagnetic iron oxide nanoparticle targeting of adipose tissue-derived stem cells in diabetes-associated erectile dysfunction. Asian J Androl. 2017;19(4):425-432. doi:10.4103/ 1008-682X.179532

197. Moghaddam SE, Hernandez-Rivera M, Zaibaq NG, et al. A new high-performance gadonanotube-polymer hybrid material for stem cell labeling and tracking by MRI. Contrast Media Mol Imaging. 2018;2018:2853736. doi:10.1155/2018/9641527

198. Qin X, Chen H, Yang H, et al. Photoacoustic imaging of embryonic stem cell-derived cardiomyocytes in living hearts with ultrasensitive semiconducting polymer nanoparticles. Adv Funct Mater. 2018;28:1. doi:10.1002/adfm.201704939
199. Lee D, Heo DN, Nah HR, et al. Injectable hydrogel composite containing modified gold nanoparticles: implication in bone tissue regeneration. Int $J$ Nanomed. 2018;13:7019-7031. doi:10.2147/ IJN.S177627

200. Sutton EJ, Henning TD, Pichler BJ, Bremer C, Daldrup-Link HE. Cell tracking with optical imaging. Eur Radiol. 2008;18 (10):2021-2032. doi:10.1007/s00330-008-0984-Z

201. Rao J, Dragulescu-Andrasi A, Yao H. Fluorescence imaging in vivo: recent advances. Curr Opin Biotechnol. 2007;18 (1):17-25. doi:10.1016/j.copbio.2007.01.003

202. Pittet MJ, Weissleder R. Intravital imaging. Cell. 2011;147 (5):983-991. doi:10.1016/j.cell.2011.11.004

203. Germain RN, Robey EA, Cahalan MD. A decade of imaging cellular motility and interaction dynamics in the immune system. Science. 2012;336(6089):1676-1681. doi:10.1126/ science. 1221063

204. Garofalakis A, Zacharakis G, Meyer H, et al. Three-dimensional in vivo imaging of green fluorescent protein-expressing $\mathrm{T}$ cells in mice with noncontact fluorescence molecular tomography. $\mathrm{Mol}$ Imaging. 2007;6(2):96-107. doi:10.2310/7290.2007.00007

205. Anderson SA, Lee KK, Frank JA. Gadolinium-fullerenol as a paramagnetic contrast agent for cellular imaging. Invest Radiol. 2006;41(3):332-338. doi:10.1097/01. rli.0000192420.94038.9e

206. Zhang J, Campbell RE, Ting AY, Tsien RY. Creating new fluorescent probes for cell biology. Nat Rev Mol Cell Biol. 2002;3 (12):906-918. doi:10.1038/nrm758

207. Newman RH, Fosbrink MD, Zhang J. Genetically encodable fluorescent biosensors for tracking signaling dynamics in living cells. Chem Rev. 2011;111(5):3614-3666. doi:10.1021/cr100002u

208. Dickson RM, Cubitt AB, Tsien RY, Moerner WE. On/off blinking and switching behaviour of single molecules of green fluorescent protein. Nature. 1997;388(6640):355-358. doi:10.1038/41048

209. Yao J, Larson DR, Vishwasrao HD, Zipfel WR, Webb WW. Blinking and nonradiant dark fraction of water-soluble quantum dots in aqueous solution. Proc Natl Acad Sci U S A. 2005;102 (40):14284-14289. doi:10.1073/pnas.0506523102

210. Zheng B, Yu E, Orendorff R, et al. Seeing SPIOs directly in vivo with magnetic particle imaging. Mol Imaging Biol. 2017;19 (3):385-390. doi:10.1007/s11307-017-1081-y

211. Croft LR, Goodwill PW, Conolly SM. Relaxation in X-space magnetic particle imaging. IEEE Trans Med Imaging. 2012;31 (12):2335-2342. doi:10.1109/TMI.2012.2217979

212. Croft LR, Goodwill PW, Konkle JJ, et al. Low drive field amplitude for improved image resolution in magnetic particle imaging. Med Phys. 2016;43(1):424. doi:10.1118/1.4938097

213. Khandhar AP, Keselman P, Kemp SJ, et al. Evaluation of PEG-coated iron oxide nanoparticles as blood pool tracers for preclinical magnetic particle imaging. Nanoscale. 2017;9 (3):1299-1306. doi:10.1039/C6NR08468K

214. Ferguson RM, Khandhar AP, Kemp SJ, et al. Magnetic particle imaging with tailored iron oxide nanoparticle tracers. IEEE Trans Med Imaging. 2015;34(5):1077-1084. doi:10.1109/ TMI.2015.2396632

\section{Dovepress}

\section{Publish your work in this journal}

The International Journal of Nanomedicine is an international, peerreviewed journal focusing on the application of nanotechnology in diagnostics, therapeutics, and drug delivery systems throughout the biomedical field. This journal is indexed on PubMed Central, MedLine, CAS, SciSearch ${ }^{\mathbb{}}$, Current Contents ${ }^{\mathbb{R}} /$ Clinical Medicine,
Journal Citation Reports/Science Edition, EMBase, Scopus and the Elsevier Bibliographic databases. The manuscript management system is completely online and includes a very quick and fair peer-review system, which is all easy to use. Visit http://www.dovepress.com/ testimonials.php to read real quotes from published authors. 